Article

\title{
Building the Future on Lessons of Historic Reinforced Concrete
}

\author{
Maria Bostenaru Dan $\mathbb{D}$
}

Department of Urban and Landscape Design, Faculty of Urbanism, "Ion Mincu” University of Architecture and Urbanism, 010014 Bucharest, Romania; Maria.Bostenaru-Dan@alumni.uni-karlsruhe.de

Received: 12 May 2020; Accepted: 20 July 2020; Published: 23 July 2020

\begin{abstract}
This contribution presents the way the construction material reinforced concrete was introduced at the beginning of the 20th century, from both the technical (Hennebique system) and the philosophical points of view. The philosophy underlying the use of this material is evident in the theories on finding a language of form corresponding to tectonics, and its dialogue with timber, formulated by certain notable practicing architects of the time across Europe. Not to be neglected are aspects relating to the conservation of material and to interventions carried out over time. In Modernist times, this meant a change from the artistic expression of Art Nouveau. Today, it means technical adaptation. The paper addresses thus sustainability of intervention versus conservation.
\end{abstract}

Keywords: 20th century architecture; historic concrete; conservation

\section{Introduction}

Concrete had existed since the Roman times, but it was Joseph Monier (8 November 1823 Saint-Quentin-La-Poterie-12 March 1906, Paris) who conceived the idea of reinforcing it, showing the idea at the Paris Exhibition 1867. Although reinforced concrete was a new material which spread during the heyday of Modernism, its language of form was sought after during the Art Nouveau period. The new material introduced at the time of Art Nouveau was iron, but the discussion on finding new forms for new materials applied equally to reinforced concrete. In many parts of Europe, unlike older buildings which are doubtless recognized as heritage, buildings from the 20th century still struggle to get this status, not being considered old enough. Also, the innovative material concrete was seen in that time as technological revolution, as we will see in this paper, but proved in history not to be an everlasting material. At that time, the material was suitable for industrial production and was also employed in industrial buildings, since the challenge of early 20th century was related to economic efficiency and industrialization. The challenges of the beginning of the century were connected to the mass movement of the population to cities, in search of work places in the context of industrialization, and this was highlighted also in the discussions (conference, films, exhibitions) of Bauhaus 100th anniversary last year (1919-2019). Today's challenges are different and related to environmental protection. Sustainability is an issue we have to take into account when thinking today of future generations, since resources are limited. The city cannot expand anymore, and these environmental issues are building a mostly invisible fortification around the city, sometimes visible as a green belt. Intensive construction replaces extensive construction. As such, the reuse of the materials they are made of or of the whole buildings of early 20th century is one of the challenges of today, especially since concrete aged and security requirements also evolved since and are not met today anymore. The sustainability of concrete as production material was addressed in [1]. Today, some buildings present challenges of security [2] against earthquake. According to the Brundtland report in 1987, 33 years ago now, the sustainability of concrete has to be put into question. Mindes and Aitcin [3] built on this affirmation when thinking of the material included in concrete, but concentrated 
on contemporary concrete. However, the reuse of existing buildings satisfies the criteria set, since new material is only sparsely produced. Hence the necessity for reuse and restoration touched in case of some of these buildings. In case of demolitions, some examples with material reuse have been shown. Sakai and Noguchi [4] look instead at the sustainable use of concrete. While looking to the history of concrete employment from Roman times and in the past century in parallel, the same issues are raised regarding material flow, but including aspects as landscape destruction and economic considerations.

Life cycle assessment is needed, and there are efforts to network internationally for this, for example in the COST (European Cooperation in Science and Technology) RESTORE "Rethink Sustainability towards a Regenerative Economy" network, including the circular economy. Historic constructions shall satisfy today's safety and energy regulations and be upgraded accordingly, while maintaining original substance in order to comply with monument protection regulations but also because of material sustainability issues. In Karlsruhe the former Institute for Industrial Production at the Faculty of Architecture is dealing now with the life cycle assessment of buildings. One of the teaching modules run is called "integral planning" and means including in the initial stages of architecture planning of all other disciplines. This can be extrapolated for existing buildings, for example, in seismic retrofitting, as done in the research of the author [5], by including building survey, economics, and structural issues while performing the architecture project of reuse.

Further to the Brundtland report, the EXPO (World exhibition) 2000 Hannover was also bound to sustainability principles, containing issues regarding the use of local materials and water. The author visited the EXPO and saw in the Netherlands pavilion an innovative employment of the principles regarding the basement-body-roof principle of a building, also in concrete [6]. Examples of the conservation of early buildings in reinforced concrete are given here in more detail for Italy. In this seismically prone country, it is not only the aging of the material that poses a problem, but also the load bearing characteristics. Several studies on such characteristics of historic reinforced concrete structures were carried out by the University of Genoa [2], for example, related to the restoration and functional conversion of the former Hotel Colombia (1921-1926) to a university library, or to the Stock Exchange building (1909-1912) (Figure 1) [7] and the Grand Hotel Miramare (1906-1908). Although Porcheddu, the agent of Hennebique in Italy was based in the North, in Turin, and most works were concentrated there, buildings made of early reinforced concrete which need repair and maintenance are found throughout the country, also in the South, like the Risorgimento bridge in Rome and Viaduct Corso Italia in Bari [8]. Later on, we will address the case of a Portuguese bridge as well.

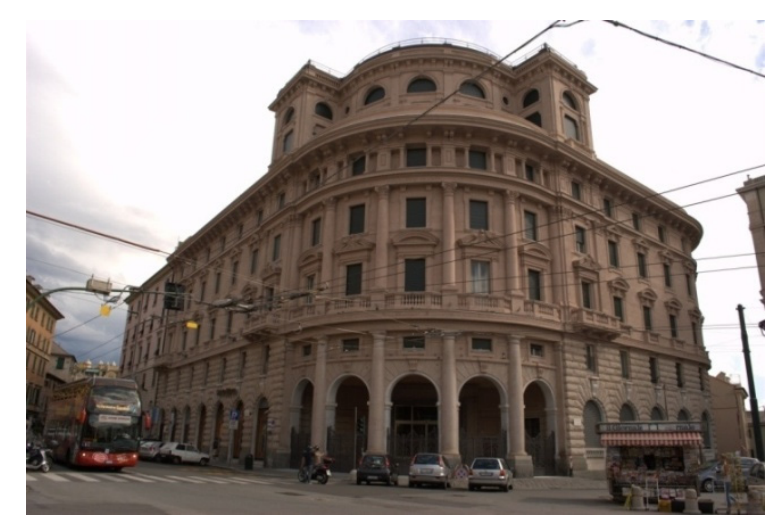

Figure 1. Functional reconversion and restoration of a reinforced concrete building Hennebique. University library (formerly hotel Colombia), Piazza Principe, Genova, Italy. (photo M. Bostenaru, 2012).

Challenges of the conservation of industrial buildings are addressed by The International Committee for the Conservation of the Industrial Heritage TICCIH [9]. The charter [9] promotes functional in situ conservation, but accepts reuse.

If demolition is unavoidable, recycled concrete [10] is an answer for a circular economy. Studies are being carried out in Portugal, at the University of Minho, using concrete from a bridge due to be 
demolished [11]. In the Bürgerparkviertel (1996-2001) in Darmstadt, Germany, on the place of dismantled industrial buildings for meat production (1887-1908) which were abandoned since 1988, new buildings were built employing recycled concrete. Kramm et Strigl [12] built so both offices and parking (Figure 2), and after the plans of Hundertwasser (15. December 1928 in Vienna-19. February 2000 Queen Elizabeth 2 in Brisbane) the first German housing building "Die Waldspirale" (forest spiral) (Figure 3) was built. In these instances, recycling concrete was used, after having been used before only in road construction [13].

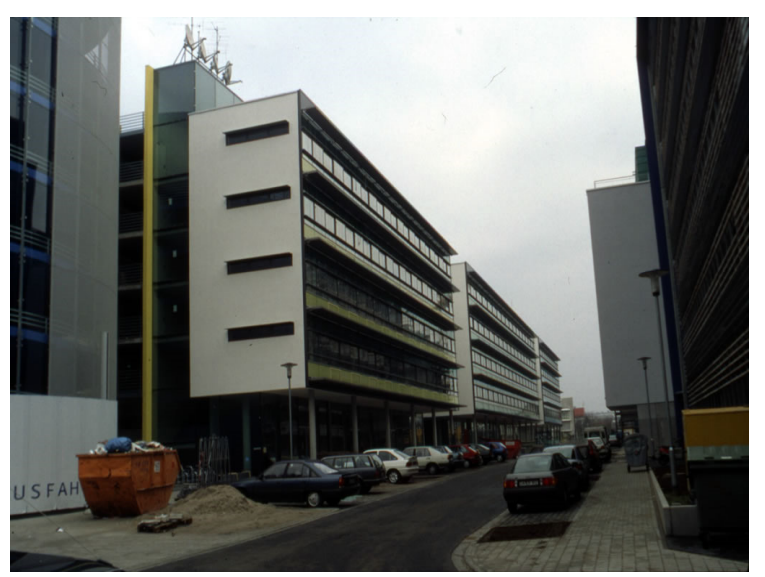

Figure 2. Bürgerparkviertel Darmstadt: the office and parking buildings with recycled concrete. (photo: M. Bostenaru, 1999).

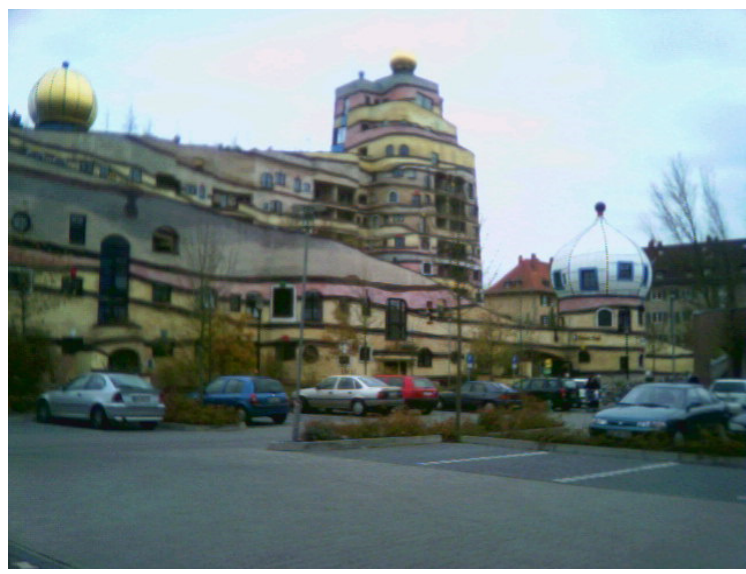

Figure 3. Waldspirale Darmstadt. (photo M. Bostenaru, 2005).

The material can also be repaired, as one innovative technology being self-healing to repair cracks, as from aging or earthquakes [14]. Magdalini Theodoridou applied this to building stone in a MSCA (Marie Skłodowska-Curie actions) project at Cardiff University [15,16].

Research methods included the analysis of historical written philosophical works (philosophy as research method in architecture), classification and analysis of photographs from the collection of the author gathered over years (presented in the work mentioned at acknowledgements), literature review including primary literature from books, journals, and conferences, news reports, and websites, including databases on the conservation state, biographies of the architects and engineers of the works, archive research, visit of exhibitions, own architecture internship in the office of Kramm et Strigl, and also editing of the author's ownbooks and attendance and presentation at relevant conferences (Riga, Milan, Guimarães) pertaining to the large subject of this research including networking. 


\section{Language for Reinforced Concrete}

In this paper, reinforced concrete will be regarded as a structural material, and, for this purpose, there will first be a review of Kenneth Frampton's view of tectonics [17], followed by an analysis of the theories and practice of early 20th century architects employing reinforced concrete. Tectonics may also be the solution to deal with the material when intervening in historical buildings, such as Anne-Catrin Schulz's [18] work on layers in the oeuvre of Carlo Scarpa.

\subsection{Review of Kenneth Frampton's Tectonics with Regard to Reinforced Concrete}

In his introduction to "Reflections on the Scope of the Tectonic", Kenneth Frampton discusses the greater scope given to the concept of tectonics. Viollet le Duc was the first to change the view on tectonics which had existed since Ancient Greek times, introducing the logic of construction. Kenneth Frampton recognizes that the study of tectonic culture aims at mediating the priority of the given space with the constructional and structural models through which it is achieved. He identifies three vectors: "topos", "typos", and "tectonic" and emphasizes the independence of tectonics from style, but not from site and type. Frampton's words are not new, however. From 1843-1852 Karl Bötticher wrote three volumes on The Tectonic of the Hellenes [19], distinguishing between 'Kernform' (nucleus shape) and 'Kunstform' (artistic shape), that is, what we nowadays call container and contents, or structural skeleton and ornamentation. In Bötticher's work, 'Kernform' refers to the timber rafters, and the 'Kunstform' "the petrified beam ends in the triglyphs and metopes of the classical entablature". This type of discourse was taken up again in essays exploring the poetics of concrete as a material, at the beginning of the 20th century. Timber was examined in the same manner, for example by István Medgyaszay, as we will later see. Bötticher's theory was taken further by the seminal work of Gottfried Semper [20], who differentiated between lightweight and mass: tectonic/stereotomics (stereotomic meaning "solid" and "cut" in Greek and being thought to be load bearing masonry). Frampton refers to this as "constructive mass and tensile frame". As Frampton notes, Semper's theory was supported by the German language, where "Wand" refers to infill walls in skeleton construction and "Mauer" refers to the heavy load-bearing wall composed of artificial or natural stones superimposed and bound with mortar.

Although already possible in timber, this kind of separation became evident with reinforced concrete, which allowed three types of relationship between structure and space: structural plan (with the heavy load bearing walls separating into functional units), free plan (where the two are distinct) and the 'Raumplan' (where spaces are connected, in a structural frame), the last named introduced by Adolf Loos. On a personal note, this is also supported by the German language, which has the word "Massivbau" meant for materials such as brick/stone and reinforced concrete, to be differentiated from timber and metal. Semper later wrote a work about materials themselves, the Stoffwechsel-theory [21], where he differentiated between wood, basketwork, and textiles, which are tensile, and stonework, brickwork, rammed earth, and reinforced concrete, which are compressive materials. However, the architects of the early 20th century identified the possibility of building the skeleton form in reinforced concrete, the wattle and daub infill type of timber. Other interdependencies exist; Frampton notes, for instance, that masonry bonds are a form of weaving. Finally, there is mention of the durability of materials; for example, mud disintegrates, and wood is ephemeral, while stone endures over time. Reinforced concrete is artificial stone. Finally, Frampton notes that Semper's theory is rooted in the emerging science of ethnography. In fact, Ákos Moravánszky, another architecture theoretician who studied Semper as well as the early reinforced concrete theory devised by Medgyaszay, also emphasized the ethnographic influences in the Central European architecture of the early 20th century [22]. The 'Kernform' and 'Kunstform' of Bötticher were developed by Semper into the technical and symbolic aspects of construction, which then were related by Frampton as "representational and ontological aspects of tectonic form" [17]. In philosophy, ontology studies the nature of being. Today, it is used in computer science, as the basis for object-oriented software design by formally representing the concepts within a domain and their relationships. Frampton [17] refers to Semper, finding that the 
earthwork, frame, and roof are ontological and the hearth and infill wall are representational or symbolic. The ontological aspect thus reflects the superposition of registries [6]. Recently, Sandaker wrote an ontology of structured space [23], presented at the same conference [11] where a discussion took place during which there was a dedicated session to this work by Frampton. In his lecture in 1905 "On the likely development of architecture", the Dutch architect Hendrik Berlage [24] also differentiated between constructive and non-constructive parts of spatial enclosure. In connecting tectonics to ontology, which is a philosophical concept, Frampton comes to Heidegger's phenomenological work "On the Origin of the Work of Art" [25] (1956, in Poetry, Language, Thought). Here, the author reflects on the relationship between material and form, examining whether the relationship has its origin in the character of the thing [26] or that of the work of art, and "conceives architecture as having the capacity not only of expressing the different materials from which it is made but also revealing the different instances and modes by which the world comes into being: 'the temple-work, in setting up a world, does not cause the material to disappear, but rather causes it to come forth for the very first time [...] The rock comes to bear and rest and so first becomes rock; metals come to glitter and shimmer, colors to glow, tones to sing, the world to speak. All this comes forth as the work sets itself back into the massiveness and heaviness of stone, into the firmness and pliancy of wood, into the hardness and luster of metal, into the lighting and darkening of color, into the clang of tine and into the naming power of world'" [17]. The paragraph is also quoted in [27] by reflecting on the relationship between technique and art, what in architecture is always the case, between technology/engineering and art. We notice that Heidegger [25] also considers the sonic space, not only the tactile. Finally, in his introduction, Frampton [17] turns to the topic of tradition and innovation, also applicable to materials, since some, as is the case with reinforced concrete, were innovative materials but sometimes under extreme conditions performed worse than traditional ones such as wood.

Tectonically significant was the iron skeleton, "ossiferous", as Frampton [17] names it, of Labrouste's Bibliothèque de Ste.-Geneviève, with its masonry and lightweight armature, to be continued by the theoretician of tectonics Viollet-le-Duc and by the reinforced concrete pioneer Auguste Perret. Finally Frampton quotes passages of Viollet-le-Duc's work, referring to the "truth" of the building in the material: "construction is the means, architecture is the result" [17], with which we come back to Heidegger's "On the Origin of the Work of Art" [25] and the truth and to today's approaches to conservation and authenticity (ex. the Nara document [28])". In 1890, some seventeen years before Francois Hennebique's decisive reinforced concrete patents of 1907, the engineer Paul Cottancin perfected his own reinforced masonry system known as 'ciment armé' [17]. Cottancin's patent becomes obsolete in 1914; it required permanent brick formwork, instead of Hennebique's temporary timber framework, another connection between reinforced concrete and timber as materials. In Cottancin's system wire reinforcement acted in tension and cement infill in compression independently, thus avoiding a weakness persisting till today in the adherence between metal and concrete. The first history of architecture to explain "the origin of the tectonic form in terms of the materials available, the structural systems employed, and the state of craft production" [17] was by Choisy, an engineer [29]. Although Le Corbusier in "Vers une Architecture" [30] was inspired by Choisy's isometric drawings, these represented better load bearing structure than skeletons, such as, for example, timber framework. Frampton deems Auguste Perret to be Choisy's follower, but he also influenced the architects of the "machine age" from Le Corbusier to Louis Kahn. "Choisy seems to have anticipated reinforced concrete as the sole technique that would prove capable of overcoming the age-old schism and fusing into a single entity the two great lines of Western building culture" [17] (which are timber construction and masonry).

In his discussion of the Germans, Frampton comes back to the duality of the ontological-representational and its synonyms (ex. core form and artistic form) which we saw at the beginning. For example, Schinkel's "Das architektonische Lehrbuch" (the architectural manual) [31] "contains many examples of differently articulated structural assemblies, rendered in different materials. In the main, these sketches are ontological rather than representational in character, that is to say 
the tectonic system itself is emphasized rather than the cladding of its form" [17], i.e., the core form predominates over the art form. We might add to this that, in the 19th century, the perception of the artistic expression of illustrations, regarded today from a technical/engineering point of view, was different.

Unlike the architects of the early 20th century, who looked for the best expression for a given material, Schinkel emphasized in this work the use of the best possible material for a given form, and highlighted the quality of craftsmanship and how the materials are joined together. Frampton returns to the analysis of Bötticher's work and the examination of the ontological status of the structure and representational status of the ornament [17]: the representational is assimilated to the Greek and the ontological to the Gothic. On a personal note, the Greeks translated timber, which is suitable for the skeleton, into masonry, while in Gothic architecture the skeleton structure was built of masonry. A philosophical influence on Bötticher comes from Schopenhauer: "architecture could only express its essential form and significance through the dramatic interaction of support (pillar) and load" [17], arguing thus for sincerity in architecture ("beauty was [...] the explanation of mechanical concepts" [17]). Not only should the core form, a mechanical-statical necessity, be expressed as such, but the art form, ornament, or cladding, should likewise be expressed as a separate part. This expression was reflected in the Secession architecture of Otto Wagner, and those influenced by his language, for example the architect from Oradea József Vágo (Figure 4). Bötticher argues for new materials, in this case iron, saying that stone had reached its apogee in the Gothic period, and that iron would be more suitable to cover large openings. A new material brings "in its train a new world of art-forms" [17]. The author sees that "the tectonic expressivity of such an unprecedented system will have to model its representational form on some kind of reinterpretation of the principles of Hellenic architecture. [...] anticipates the semiotic transformations of Jugendstil in its crystallizing phase, particularly [...] Otto Wagner" (The principles of the Hellenic and Germanic way of building [19]). In the Stoffwechsel-theory Semper [19] observes the transformation through mythical, originally tensile construction into petrified compressive forms (the Greeks' timber in stone). The nomadic textile forms were transformed into a permanent material when bricks became "dressing", which we can see also in connection with Deleuze's smooth and striated space [32], when distinguishing between nomad and sedentary. Otto Wagner pushed Semper's theory further: "a new style must depend of necessity on a new means of construction" [33]. Wagner was, according to Frampton, the heir of Schinkel, Bötticher and Semper. "New purposes must give birth to new methods of construction and by this reasoning also to new forms" [34], so a new Kunstform derives from a new "Werkform, as inorganically articulated structural invention" [35]. He applied Semper's theory of dressing with the tiles and nails on the Postsparkasse.

The chapters which follow in [17] are dedicated to the analysis of tectonics in the work of several architects: Frank Lloyd Wright (8 June 1867, Richland Center-9 April 1959, Phoenix) where he identifies the so-called "text-tile" tectonic, the reinforced concrete pioneer Auguste Perret (12 February 1874, Ixelles, Belgium-25 February 1954, Paris) (Figure 5) and his contemporary Henri Sauvage (10 May 1873, Rouen-21 March 1932, Paris) and so-called "classical Rationalism", Mies van der Rohe (27 March 1886, Aachen-17 August 1969, Chicago) and the Avant Garde, Louis Kahn (20 February/5 March 1901, Kuressaare, Estonia, Russian Kingdom-17 March 1974, New York) vis à vis Modernism, Jørn Utzon (9 April 1918, Copenhagen-29 November 2008, Helsingør) and the tectonic metaphor in trans-cultural form, and finally the joints designed by Carlo Scarpa (2 June 1906, Venice-28 November 1978, Sendai, Japan) in the late 20th century. The work of Carlo Scarpa and the interpretation in [18] is also touched thus in [17]. 


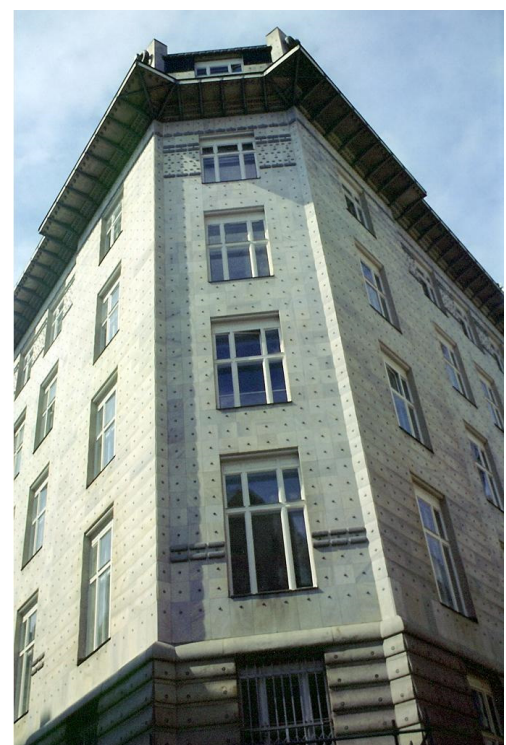

(a)

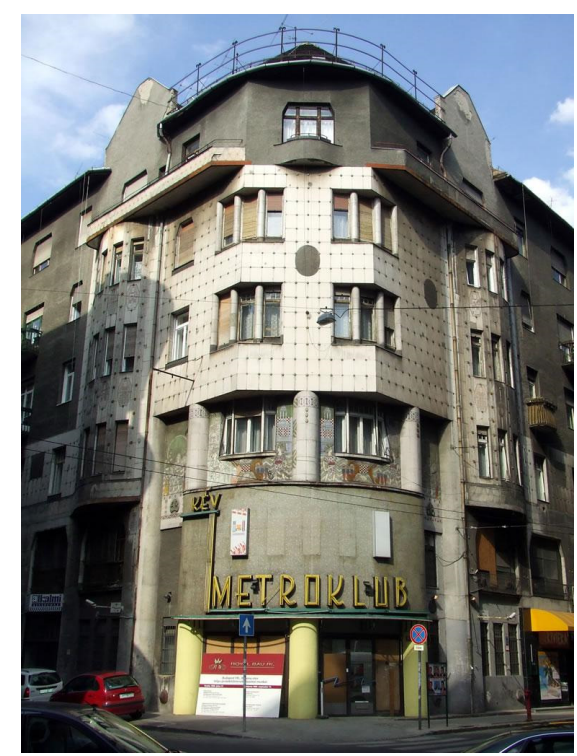

(b)

Figure 4. Otto Wagner's influence: (a) Postsparkasse, Vienna, architect Otto Wagner 1904-1906; (photo: M. Bostenaru, 2005); (b) Arkaden-bazár, Budapest, architect József Vágo, 1909; (photo: M. Bostenaru, 2003).

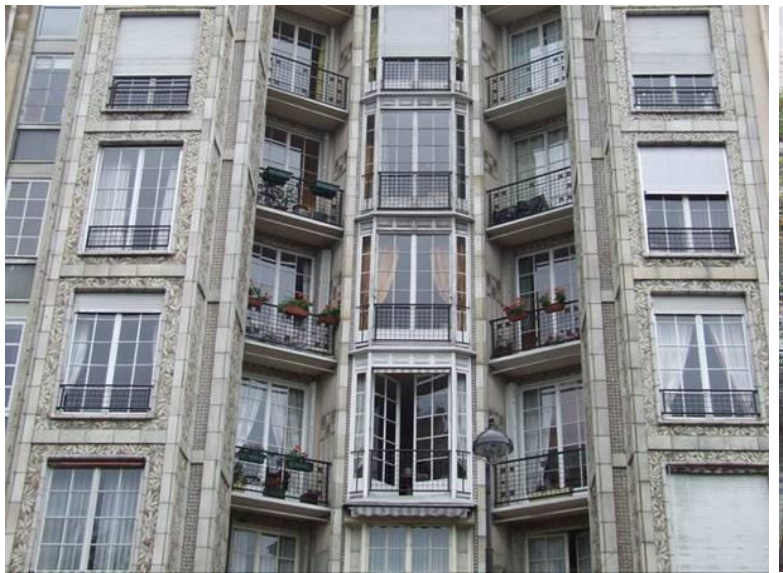

(a)

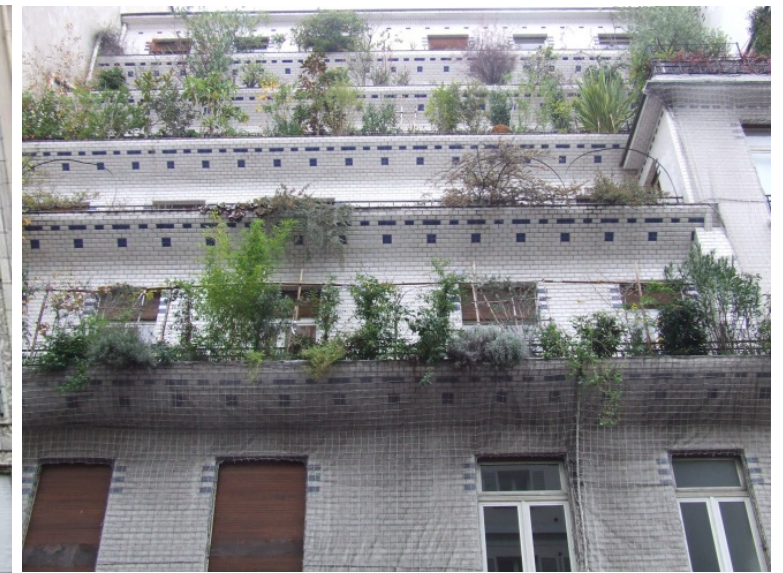

(b)

Figure 5. Early use of reinforced concrete with Art Nouveau reminiscences in Paris: (a) Block of flats on Rue Franklin, architect Auguste Perret (1902-1904). (b) Block of flats on Rue Vavin 26, architect Henri Sauvage (photos: M. Bostenaru, 2010).

\subsection{Essays}

In Italy (Torino, Mina [36]), Belgium (Henri van de Velde [37]), and Hungary (István Medgyaszay [38]), practicing architects were seeking a language for reinforced concrete. Erich Mendelsohn reflected on the use of concrete in the Einstein tower in Potsdam, Germany, to the language developed for concrete by Henri van de Velde, as is evident in his letters [37]. The Einstein tower (Figure 6a) is considered to express concrete in an appropriate shape, but it was mainly made of brick and iron. This was also foreconomic reasons, iron being a widely used material in industrial Germany during that time. This and the whole challenges of restoration are written in Huse [39]. Challenges of restoration included the thermal bridges of iron and concrete not being covered by sufficient brickwork. A similar example of a dynamic form suitable for concrete is seen in Béla Lajta's block of flats on Népszinház street (Figure 6b), which is classified by Ákos Moravánszky 
as neither belonging to the Secession nor to the National Romantic style, but to "the new language of reinforced concrete" [40]. However, a visit on site reveals the same structure as in the case of the Einstein Tower. Lajta seems to have turned to reinforced concrete with the Rózsavölgyi house, as we will later see. Van de Velde saw a connection between the shape to be used for concrete and that used for timber, and this view was not unique. The opinion was shared by the Hungarian István Medgyaszay, who was a student of Otto Wagner, and expressed his views both theoretically [38] in a lecture in Vienna and practically, in the concept of the theatre in Veszprém, Hungary. In his seminal book on tectonics, Kenneth Frampton [17] gives an exhaustive explanation on how reinforced concrete should be included among tensile materials such as timber, and their petrified versions inherited from the Greeks, which is the load bearing masonry, and which acts in compression. The simple differentiation in skeleton structure and load bearing masonry is not enough, since skeleton structures were made out of stone during the Gothic period.

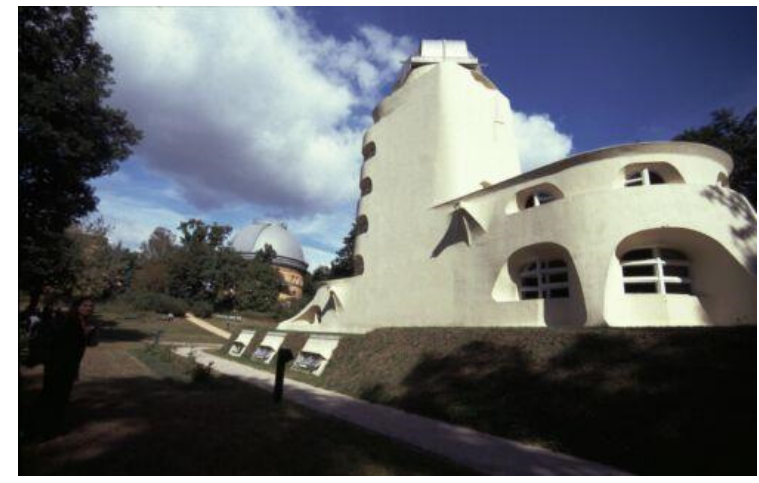

(a)

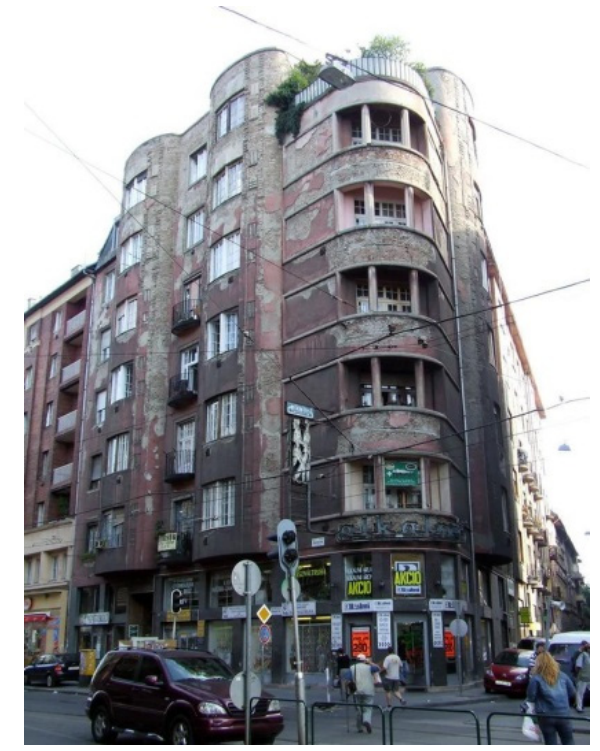

(b)

Figure 6. The shape of reinforced concrete. (a) 'Einstein Tower', architect Erich Mendelsohn (1919-1921) (photo: M. Kauffmann, 2002), (b) Block of flats on Népszinház street, Budapest, architect Béla Lajta (1911) (photo: M. Bostenaru, 2006).

\section{PracticeFollowing the Essays}

Some works by István Medgyaszay (23 August 1877 in Budapest, then Austria-Hungary-29 April 1959 in Budapest, Hungary) in Veszprém and Balatonalmádi, both in Hungary, as well as some projects published 1902 and 1903 in 'Der Architekt', in Vienna, before graduation, will be presented to see the connections between theory and practice. István Medgyaszay was a student of Otto Wagner (13 July 1841 in Penzing by Vienna-11 April 1918 in Vienna) at the master school 'Spezialschule für moderne Architektur' (Special school for modern architecture).Gotfried Semper (29 November 1803 in Hamburg, Germany-15 May 1879 in Rome, Italy) separates out the construction according to the principle of the primitive hut. The floor, wall and ceiling typology generated Loos' 'Raumplan' (Adolf Loos 10 December 1870 in Brno, then Austria-Hungary, today Czech Republic-23 August 1933 in Kalksburg by Vienna, Austria), but in the search for a technically advanced and artistically convincing style for reinforced concrete Wagner's student István Medgyaszay went the furthest. He worked with Hennebique (25 April 1842 in Neuville-Saint-Vaast-20 March 1921 in Paris) in Paris (1907), but his architecture does not show the French influence and is fundamentally different from Auguste Perret's (12 February 1874 in Ixelles, Belgium-25 February 1954 in Paris) 'Theatre of the Champs Elysees' in Paris (1913) (Figure 7), the later taken over from Henri van de Velde the theory of whom was introduced 
above. In the lecture "on the artistic solution of reinforced concrete construction" [38], Medgyaszay expressed his thoughts about the separation between design and space limitation. The structural elements of the building should be designed in accordance with this application. Thus, Medgyaszay emphasized the flat character of the horizontal separating building elements.

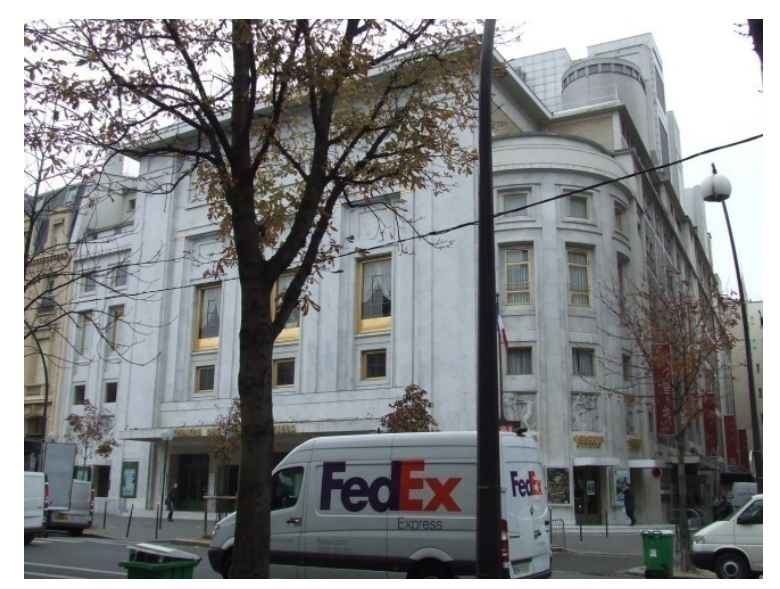

Figure 7. 'Theatre of the Champs Elysees' (Paris, 1913) architect Auguste Perret (photo: M.Bostenaru, 2010).

The effort to explore the specific mechanical characteristics (resistance) of the new material ferro-concrete in order to characterize and to find an artistic expression in the shape language for reinforced concrete is important for architectural history. Medgyaszay also sees the artistic relationship of reinforced concrete with timber. The new and important aspects of the theater in Veszprém, Hungary (1908) were also formulated in the lecture. Medgyaszay was no stranger to the national style, but here his design transcends the Oriental character of the extremely logical and honest construction, reflecting his view of the artistic element: the problems of the time were more important than the creation of an architectural style.

The Theatre in Veszprém (Figure 8a) is a multi-purpose hall for a small town. It is situated in the former Bishop's garden, which is considerably lower than the adjacent road. The auditorium measures $20 \times 16$ sqm [37], is sloping and balanced, being suitable for transformation.

The theater space is covered by a double-shell construction. The inner shell of the auditorium consists of reinforced concrete decorative grilles for air heating and is hung on a very thin barrel-shaped reinforced concrete structure between T sections of iron. The building was 'air-conditioned' with heating and thus the windows cannot be opened. The window construction consists of reinforced concrete bars with glued glass windows, a patented solution.

The almost brutal-looking ceiling in the foyer is made of precast reinforced concrete, featuring concrete lattice-work, and decorative concrete structures with a bonded glass window determine the formal look of a cast concrete house, in a different manner from Mendelsohn's 'Einstein' tower in Potsdam, Germany (1919-1921) and from Lajta's building in Budapest (1911).

Perforated reinforced concrete surfaces are typical of Medgyaszay's approach to the material, and can also be seen in the Laczkó Dezsó museum building in the same city (Figure 8b), which is, however, less innovative. As highlighted in the lecture, this might derive from the timber approach, as we see in the church in Balatonalmádi (1930) (Figure 8c). However, solutions were found for reinforced concrete, and we may see projects which are suitable for the new material from the period he spent studying in Vienna, as published in 'Der Architekt' [41,42]. 


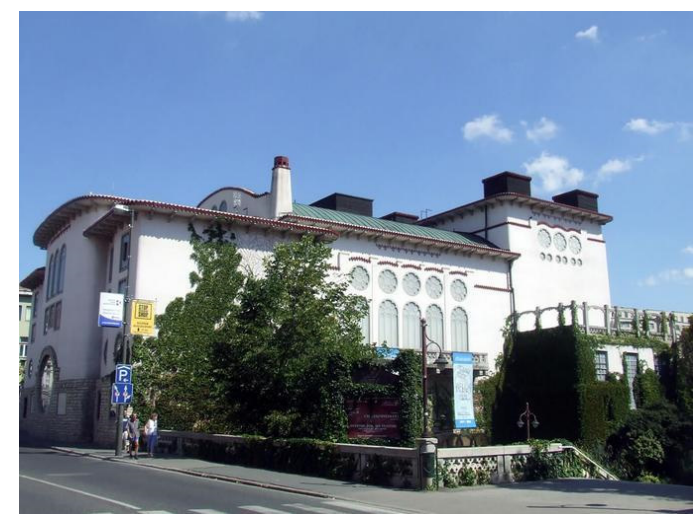

(a)

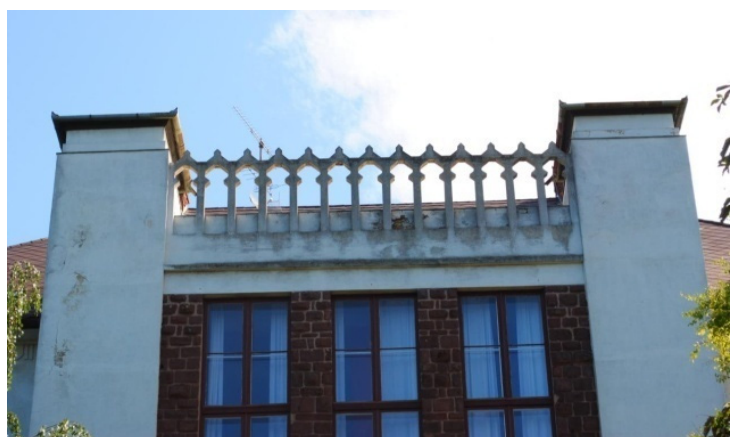

(b)

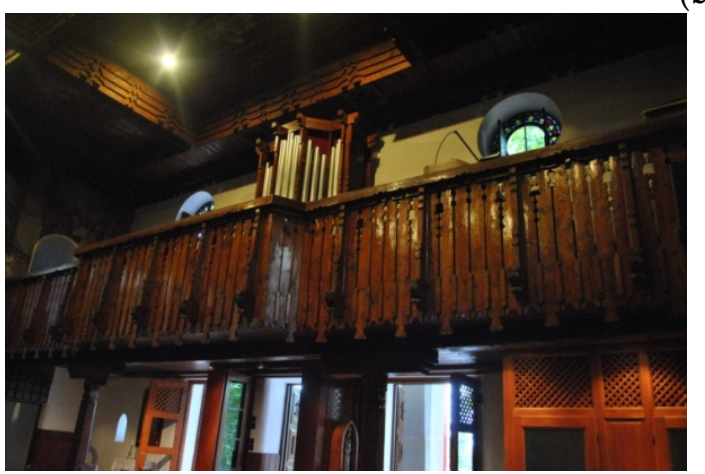

(c)

Figure 8. Architecture of IstvánMedgyaszay (a) Theatre, Veszprém (1908) (Photo: M. Bostenaru, 2006), (b) Reinforced concrete perforated details at the LackóDezső Museum, Veszprém (1912), (c) Church in Balatonalmádi (1930) (photos: M. Bostenaru, 2011).

\section{The Spread of the Hennebique'System}

As well as considering the efforts made to examine the philosophy of the material, it is worth studying how it was actually used technically. In the patented drawing on the Hennebique system a network of primary and secondary reinforced concrete beams and joists is visible. This is a characteristic which was not kept in later reinforced concrete skeleton constructions, where the hierarchy of primary and secondary was often mixed. The German language differentiates between this early reinforced concrete and the later version, calling the first iron-concrete ('Eisenbeton') and the later steel- concrete ('Stahlbeton'), while in English for this early version also ferro-concrete is used. In Hungarian however 'vasbeton' is used for both. In Romanian, Italian, and French, the material is called in a similar way to 'reinforced concrete', not differentiating between the kind of reinforcement.

Hennebique's headquarters were in Brussels, and from there the system spread through offices and contractors throughout Europe and beyond. Table 1 and Figure 9 show the location of the examples of the spread considered in this paper. 
Table 1. Studies considered.

\begin{tabular}{|c|c|c|c|}
\hline Country & Name of Work & City & Intervention \\
\hline \multirow[t]{9}{*}{ Italy } & Palazzo della Borsa & Genoa & Restored \\
\hline & Grand Hotel Miramare & Genoa & Restored \\
\hline & Porto Antico & Genoa & Restored + extension \\
\hline & Via XX Settembre & Genoa & Preserved as is \\
\hline & Mercato Orientale & Genoa & Preserved as is \\
\hline & Silos & Genoa & Call for tender \\
\hline & Ponte del Risorgimento & Rome & Preserved as is \\
\hline & Lingotto & Torino & Restored + extension \\
\hline & Ponte Corso Italia & Bari & Need for restoration \\
\hline \multirow[t]{14}{*}{ Romania } & Bulevardul Magheru & Bucharest & Red dot policy calling for restoration \\
\hline & Athenée Palace & Bucharest & Transformed more times \\
\hline & Block of flats on Frumoasă street & Bucharest & Preserved as is \\
\hline & Water tower at Medicine faculty & Bucharest & Demolished \\
\hline & Water tower on Știrbey domain & Buftea near Bucharest & Preserved as is \\
\hline & Cernavodă Bridge & Cernavodă & Closed \\
\hline & Silos & Constanța & Different suggestions for restoration \\
\hline & Casino & Constanța & Call for tender \\
\hline & Mosque Carol I & Constanța & Preserved as is \\
\hline & Silos & Galați & Preserved as are \\
\hline & Silos & Brăila & Preserved as are \\
\hline & Water tower & Brăila & Restored \\
\hline & Moskovits Miksa Palace & Oradea & Restored \\
\hline & Water tower at CFR locomotive depot & Timișoara & $\begin{array}{l}\text { Neglected, unlike other ones in the } \\
\text { same city }\end{array}$ \\
\hline \multirow[t]{11}{*}{ Hungary } & Arkaden-Basar & Budapest & Restored \\
\hline & Building on Népszinház street & Budapest & Neglected \\
\hline & Rózsavölgyi house & Budapest & Preserved as is \\
\hline & Water tower on Margaret island & Budapest & Restored \\
\hline & Water tower on Svábhegy & Budapest & Preserved as is \\
\hline & Petőfi theatre & Veszprém & $\begin{array}{l}\text { Restored 1984-1988, functional } \\
\text { adaptation keeping main character }\end{array}$ \\
\hline & Laczkó Dezső museum & Veszprém & Restored in the $1980 \mathrm{~s}$ \\
\hline & Szent Imre church & Balatonalmádi & Preserved as is \\
\hline & Water tower & Siófok & Restored \\
\hline & Reők palace & Szeged & Restored \\
\hline & Water tower & Szeged & Restored \\
\hline \multirow[t]{3}{*}{ Austria } & Loos house & Vienna & Preserved as is \\
\hline & Church of Holy Spirit & Vienna & Preserved as is \\
\hline & Postsparkasse & Vienna & Restored \\
\hline \multirow[t]{4}{*}{ Portugal } & Luis Bandeira Bridge & Rio Vouga & Submerged to a dam \\
\hline & Water tower & Barreiro & Call for tender \\
\hline & Water tower, Penha de Franca & Lisbon & Preserved as is \\
\hline & $\begin{array}{l}\text { Faculty of Medicine, University of } \\
\text { Lisbon }\end{array}$ & Lisbon & Preserved as is \\
\hline \multirow[t]{2}{*}{ Latvia } & Water tower of Agenskalns & Riga & Preserved as is \\
\hline & Water tower Čiekurkalns & Riga & Preserved as is \\
\hline \multirow[t]{4}{*}{ Germany } & Bürgerparkviertel & Darmstadt & New development in historic site \\
\hline & Einsteinturm & Potsdam & Restored \\
\hline & ZKM & Karlsruhe & Restored + extension \\
\hline & Speicher Altona & Hamburg & Restored + extension \\
\hline Egypt & Baron Palace & Cairo & Subject of investigation from Vienna \\
\hline Israel & Water tower & Tel Aviv & Restored \\
\hline \multirow[t]{4}{*}{ France } & Block of flats Rue Franklin & Paris & Preserved as is \\
\hline & Théâtre des Champs-Élysées & Paris & Restored \\
\hline & Block of flats Rue Vavin & Paris & Restored \\
\hline & Villa Hennebique & $\begin{array}{l}\text { Bourg-la-Reine near } \\
\text { Paris }\end{array}$ & Altered in time \\
\hline
\end{tabular}




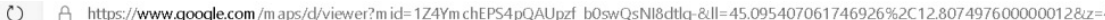
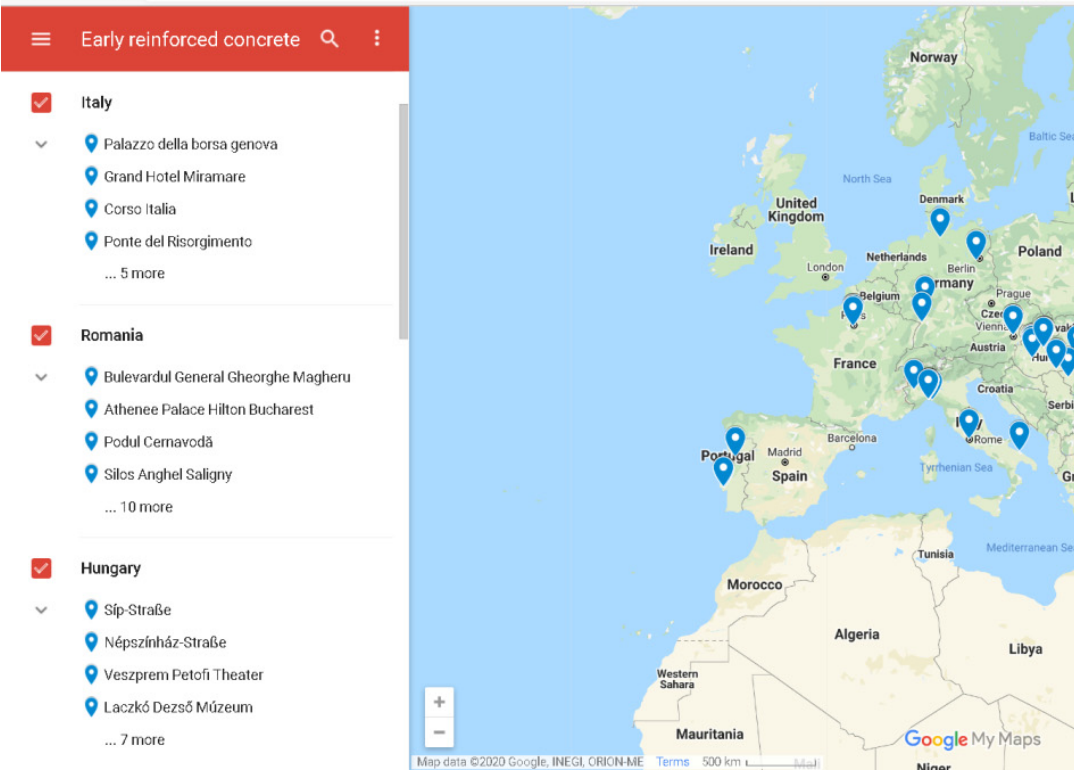

Figure 9. Map of case studies mentioned in this paper. Full map here: https: //www.google.com/maps/d/drive?state=\%7B\%22ids $\% 22 \% 3 \mathrm{~A} \% 5 \mathrm{~B} \% 221$ Z4YmchEPS4pQAUpzf_ b0swQsNI8dtlg-\%22\%5D\%2C\%22action\%22\%3A\%22open $\% 22 \% 2 C \% 22$ userId $\% 22 \% 3 \mathrm{~A} \%$ $22103245202827861421792 \% 22 \% 7 D \& u s p=$ sharing.

\subsection{Early Reinforced Concrete in Italy}

The discussion starts with Italy, as it was already mentioned in the introduction. In Italy the representative of the Hennebique system was Giovanni Antonio Porcheddu (26 June 1860 Ittiri-17 October 1937 Turin), who was based in Turin and was active all over Italy, especially in the north [43]. The archive can be consulted on request [44]. The FIAT Lingotto factory (1916-1923) (Figure 10) by Giacomo Matté Trucco (30 January 1869 in Trivy-15 May 1934 in Turin) is one of the examples of industrial architecture which gained importance, also on account of contemporary conversion (1983-2002) by Renzo Piano (14 September 1937, Genoa) and because of its integration in the 2006 Winter Olympic Games. However, it is Genoa where a boulevard was traced at the turn-of-the-century with buildings constructed according to Hennebique's new system, namely the Via XX Settembre (Figure 11).

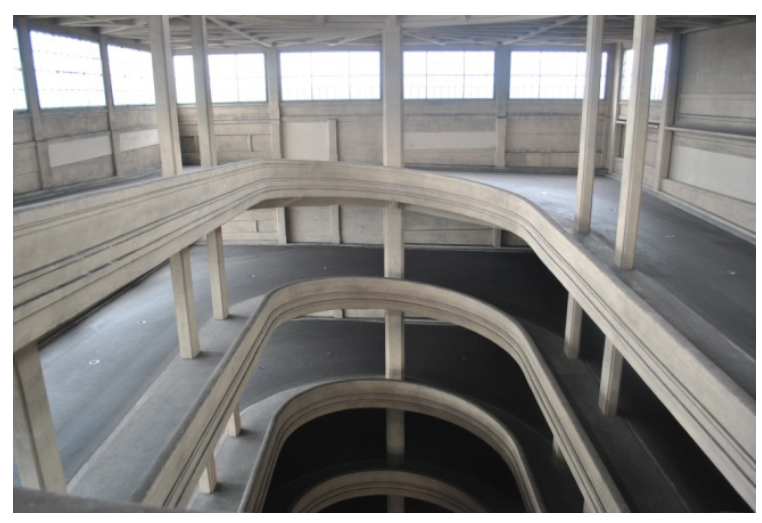

(a)

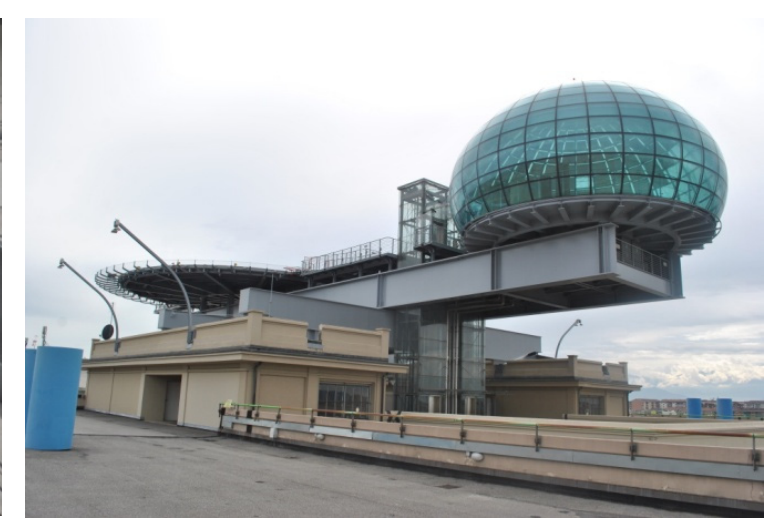

(b)

Figure 10. FIATLingotto factory, today Polytechnic of Turin, Italy. (a) reinforced concrete elements;(b) additions in the conversion process. (photos: M. Bostenaru, 2018). 

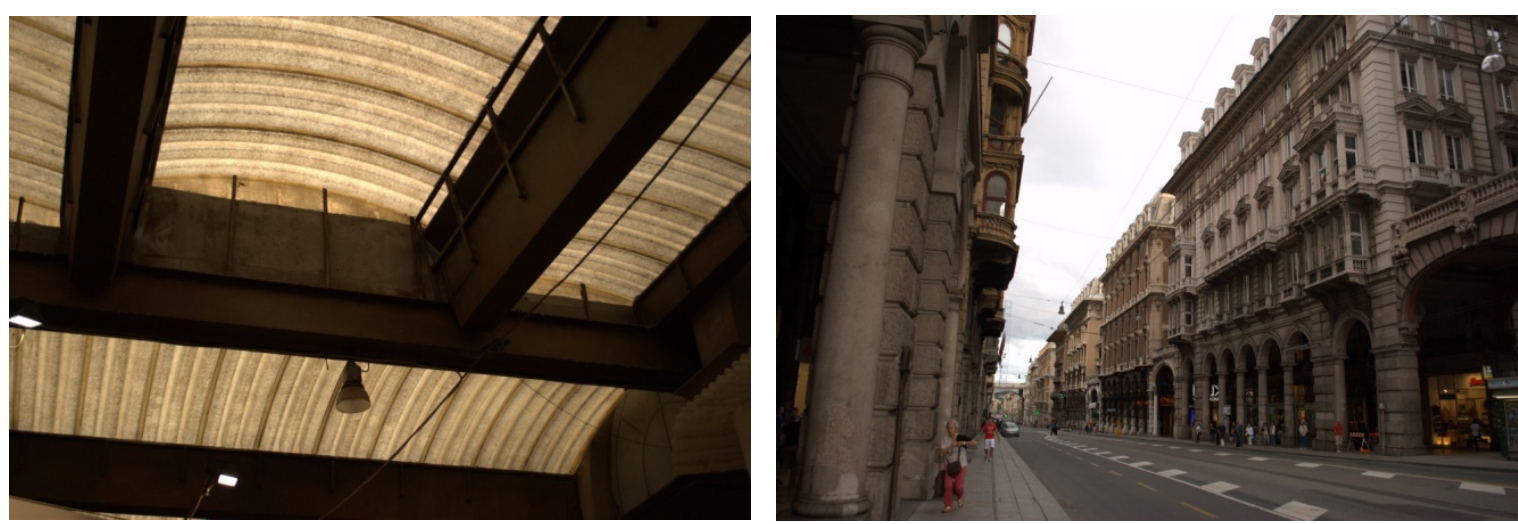

Figure 11. Via XX Settembre Genoa, Italy, incl. Mercato Orientale (on the left), a Hennebique type intervention in Italy (photos: M. Bostenaru, 2012).

\subsection{Romania}

In Bucharest, a boulevard similar to Via XX Settembre in Genoa, featuring early reinforced concrete constructions, but with a skeleton structure, unlike the Hennebique method, was completed in the interwar period in the Modernist style (Figure 12). The buildings on this boulevard were damaged in the 1940 and 1977 earthquakes, with partial and total collapse followed by the altering and replacement of the damaged buildings, losing much of the initial unity, and retrofitting today may further alter their appearance.

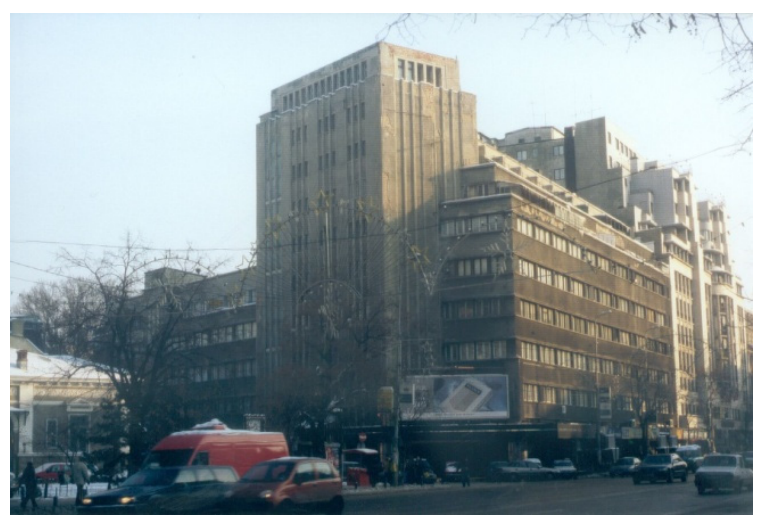

Figure 12. Magheru boulevard in Bucharest with the building which was the Modernist manifesto (ARO—Asigurarea Românească—building by architect HoriaCreangă, from 1929). (photo: M. Bostenaru, 2002).

The first example of early reinforced concrete in the Hennebique system in Bucharest, Romania, is the Athenée Palace (1910-1912) (Figure 13). The initial architecture design was done by the architect of French origin but born in Romania Daniel Renard (1871 in Dragomirești, Romania-1936?) and the civil engineer George Constantinescu (4 October 1881, Craiova, Romania-11 December 1965, Coniston, UK), a student of Anghel Saligny (19 April 1854, Șerbănești-17 June 1925, Bucharest), the renowned engineer of the Cernavodă bridge (1890-1895), the longest at the time in Europe. Anghel Saligny also employed reinforced concrete in the silos of Brăila and Galați (1886) in the Danube harbours, shortly after the Monier patent, and at the silos in Constanț (1899/1904-1909, in the later years employing 'Holzcement'), on the seaside, the latter after the plans of architect Petre Antonescu, with neoclassical architecture. The silos of Constanța are listed as monument in Romania and were the first in pre-cast concrete. Anghel Saligny studied in Germany, where the patents of Monier arrived 1884-1887 [45]. The silos in Constanța were also subject of recent conservation discussion, for which Irina Băncescu pursued some studies of intervention and conservation, including also a view on 
contemporary silos and harbours, for example the Hafen City in Hamburg by Possehl \& Co., 1896, so at a close date but still in brick [46] which the author visited (Figure 14).The silos in Constanța can be compared to the situation of the Hennebique silos (1901) in Genoa, where engineers A. Carissimo, G. Crotti, and G. B. De Cristoforis, performed by Porcheddu in Art Deco style. Since 2007, the silos in Genoa bear the label of "site of artistic interest" [47]. In fact, both studies on historic reinforced concrete on the Romanian seaside were performed in Italy and this highlights the connection to case studies there (Figure 15). The silos of Genoa first were subject of some graduation thesises at both at the University of Genoa and the Turin Politechnic. They are in state of abandon since 1980s, and there is a call for tender to restore them. They are neighboring the Genoa old harbor regenerated by Renzo Piano in 1988-2001, who also regenerated FIAT Lingotto. Daniel Renard is also the creator of another representative Art Nouveau building on the territory of the Old Kingdom of Romania: the Casino in Constanța (1909) (Figure 16) [48]. The Casino is today in advanced state of deterioration, but finally after intense discussions (it was included in the seven most endangered by Europa Nostra in 2007 [49], steel and concrete corrosion in the few concrete elements being identified as some of the issues) for this emblematic building 2019 restoration works started. The engineer George Constantinescu also designed the structure for the first building in reinforced concrete in Romania (reinforced concrete was used for the cupola and the minaret), the Mosque in Constanța (1910-1913) (Figure 17), also with New-Romanian elements, architect Victor Ștefănescu (14 March 1877-1950), designed after the model of the mosque in Konya, Turkey [50], and for the Casino. The facade of the Athenee Palace in Bucharest, Romania, had already been changed during the interwar period by a Modernist intervention related to the Italian Novecento style carried out by the architect Duiliu Marcu (25 March 1885 in Calafat, Romania-9 March 1966, Bucharest), in 1937 [51]. In addition, the Athenée Palace in Romania underwent a new restoration in the $21^{\text {st }}$ century, aimed mainly at increasing its seismic performance, but also connected to its conversion into a Hilton hotel. Another student of Anghel Saligny was the engineer Elie Radu (20 April 1853, Botoșani-10 October 1931), who designed bridges, roads, and railways as well as some water works, including the water towers in Brăila (Figure 18) and Drobeta Turnu-Severin, both cities on the Danube. The water tower in Brăila has been altered in the 1980s during Socialism, but after 2018 renovated with European funds, like the one in Drobeta Turnu-Severin. Anghel Saligny himself designed the water tower at Știrbey palace, a mid-19th century palace of a Walachian prince in Buftea, near Bucharest in 1920 in reinforced concrete. It was less important in the curriculum of Saligny and not detailed in [45], but it is nevertheless listed as monument of national importance in Romania, while several water towers are listed as local importance monuments.

On the territory of the Old Kingdom of Romania during the Art Nouveau period the 'New Romanian' style was the new style introduced at the turn-of-the-century. This was inspired by the vernacular Romanian construction of the so-called "cula" (fortified housing in Muntenia) but also the cult architecture of the Brâncovenesc style, as promoted by the Medieval Voivod Constantin Brâncoveanu. It can be found in some monasteries or residences (Mogoşoaia), but was also characteristic of some now-vanished monuments (the Vacăreşti monastery 1716-1736, demolished 1986 by the order of Nicolae Ceaușescu). Other Romanian architects such as Virginia Andreescu-Haret [52], argued during Communism as the first female architect in the world, nevertheless the first in Romania and the first in the world depending on criteria such as 'practicing after proper graduation', adhered to this style despite staying in Italy for a while for study, before turning to modernism. An interesting aspect of Virginia Haret's work is, however, the fact that the first block of flats in reinforced concrete in Romania, situated on Frumoasă street corner to Calea Victoriei (1924-1928) (Figure 19), has been attributed to her. This block of flats has a different style from both New-Romanian and Modernism, and is referred to as eclectic [53], so there is a debate about who actually created the building. Virginia Haret also planned industrial constructions in early reinforced concrete, such as a water tower in the courtyard of the former Faculty of Medicine (1927), which had New-Romanian architectural elements and was later demolished (Figure 20). 
In Transylvania, which was part of the Austro-Hungarian empire and not of the Romanian Old Kingdom, there are also examples of the Hennebique system, in Oradea (the Moskovits Miksa palace from 1904-1905, in the Munich Secession style, the so-called Lilienstil, [54], Figure 21). The Secession style shows close connections to Hungarian architecture. In the construction of the Moskovits Miksa palace by Kálmán Rimánoczy jr. (1892-1912) precast iron concrete slabs, so-called Hennebique plates [55] have been used for the first time in Oradea after the plans of Professor of engineering Szilárd Zielinszky (1 May 1860 in Mátészalka, Austro-Hungary-24 April 1924 in Budapest, Hungary), a pioneer of reinforced concrete in Hungary who worked in France at Gustave Eiffel and, after knowing the Hennebique patents, lobbied for these in Hungary. The palace has been recently restored, after an extensive 3D scanning campaign in 2016-2017.On the territory of Romania Zielinszky constructed the railway water tower (Depoul CFR) in 1905 in Timișoara by the same contractors as the tower in Szeged. In Timissoara there are two other twin water towers in Iosefin (1913-1914) and Fabric neighborhoods. For the first, designed by Art Nouveau architect Lászlo Székely (3 August 1877 in Nagyszalonta, Hungary-23 January 1934 in Timișoara, Romania), in 2019, a conversion program was announced with a coffee shop and coffee museum. Víztorony [56] is a database of water towers on the territory of Hungary, Romania, Slovakia, which were part of the Austro-Hungarian Empire at the time they were built.

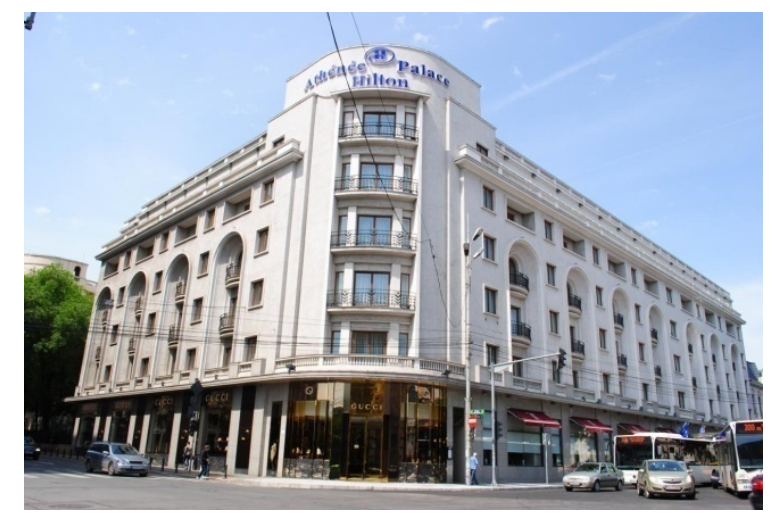

Figure 13. Athenee Palace after the Modernist changes by architect Duiliu Marcu, Bucharest (photo: M. Bostenaru, 2011).

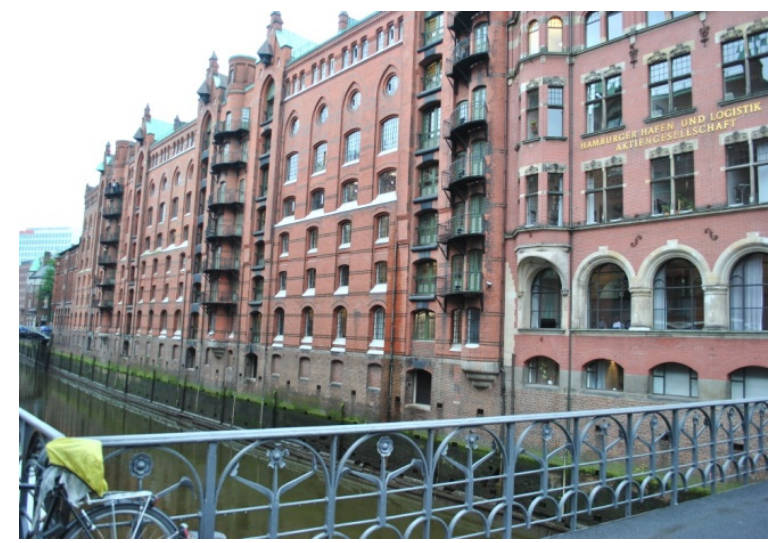

Figure 14. HafenCity in Hamburg (photo: M. Bostenaru, 2012). 


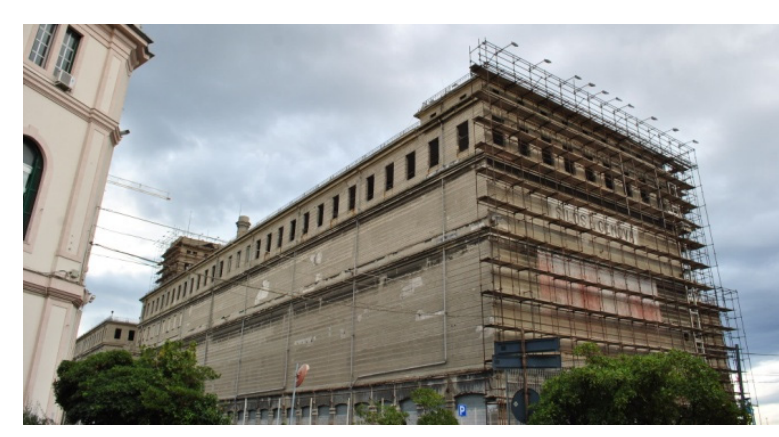

(a)

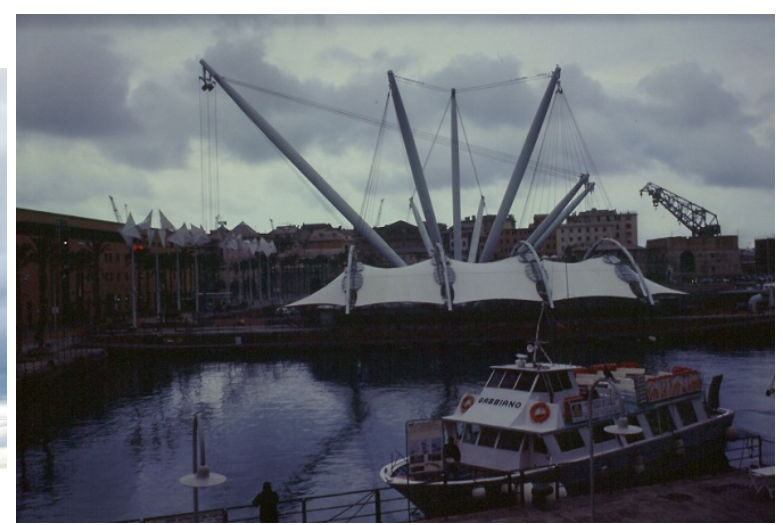

(b)

Figure 15. Industrial architecture in reinforced concrete: (a) Silos in Genova (1901) during restoration; (b) old harbor with Renzo Piano addition. (photos: M. Bostenaru, 2012).

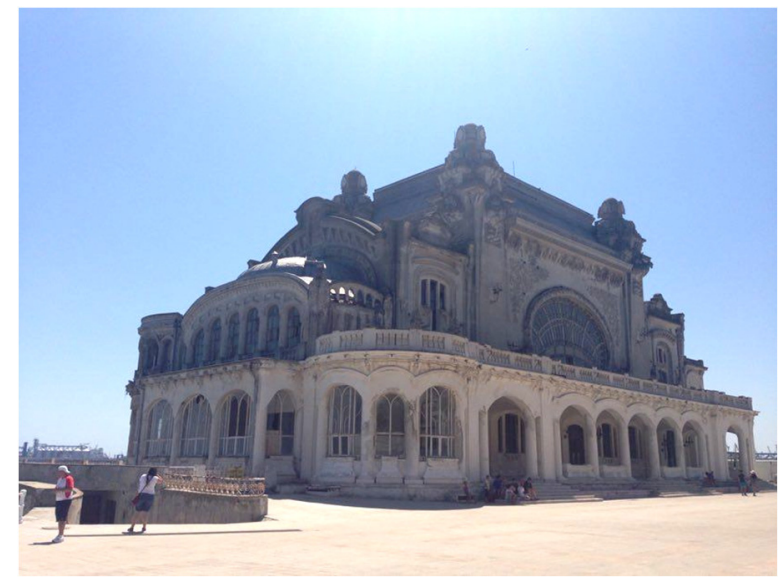

Figure 16. Casino in Constanța, Romania, architect Daniel Renard (1909) (photo: A. Bălăceanu).

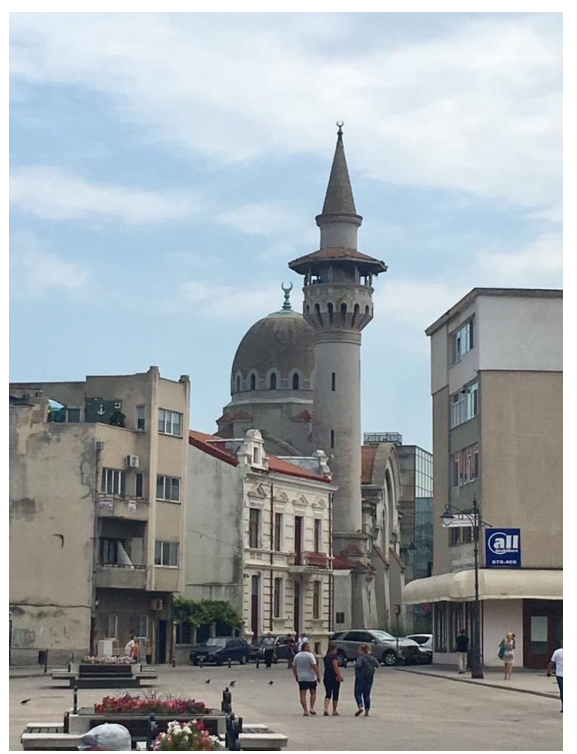

Figure 17. Carol I Mosque in Constanța, Romania (1910-1913), architect Victor Ștefănescu (photo: A. Bălăceanu). 


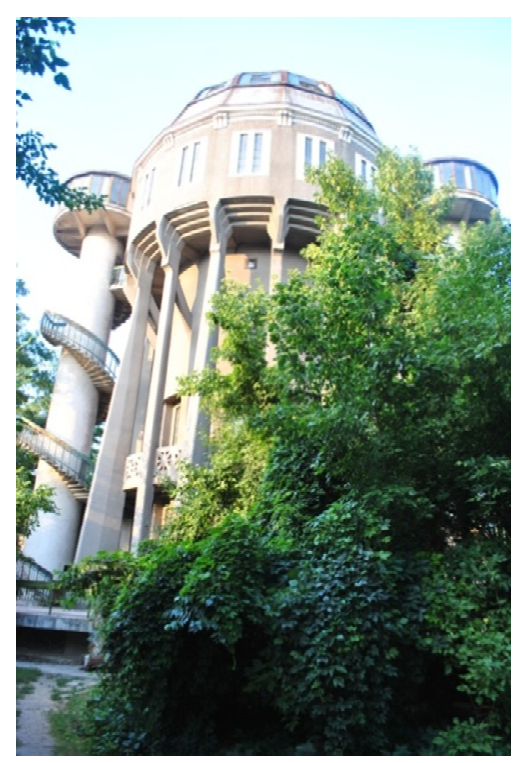

Figure 18. Water tower in Brăila, engineer Elie Radu (1912-1913) (photos: M. Bostenaru, 2013).

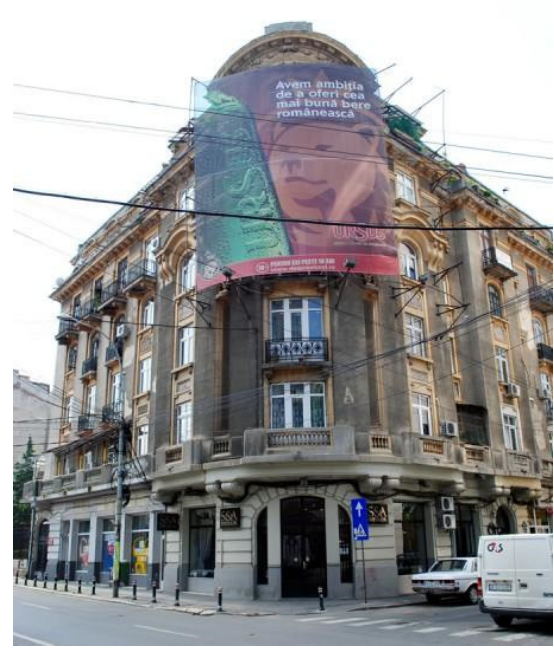

(a)

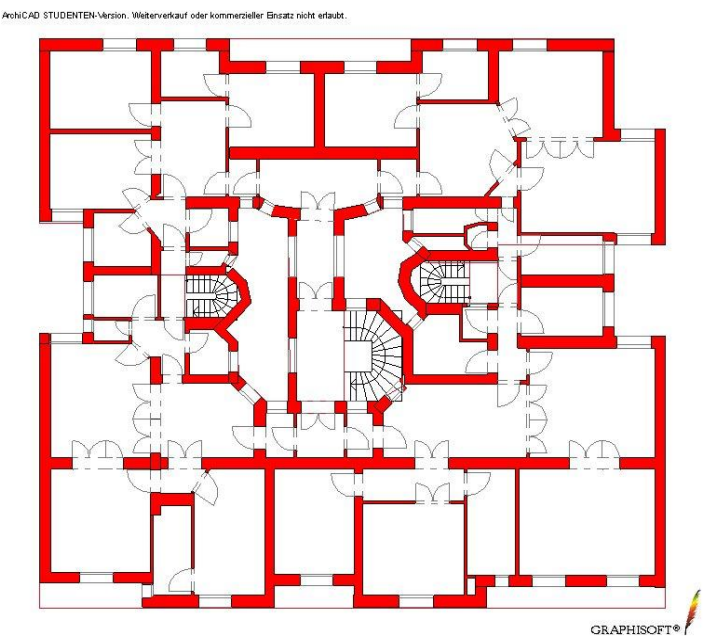

(b)

Figure 19. Block of flats on Frumoasă street 50-56 by Virginia Haret(1924-1928) ((a) photo and (b) plan drawing of a module of two apartments, not the corner module: M. Bostenaru, 2011). 


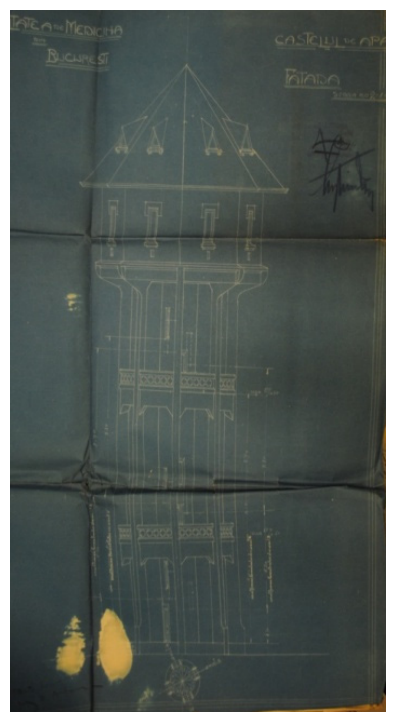

Figure 20. Water tower by Virginia Haret (Bucharest city archives).

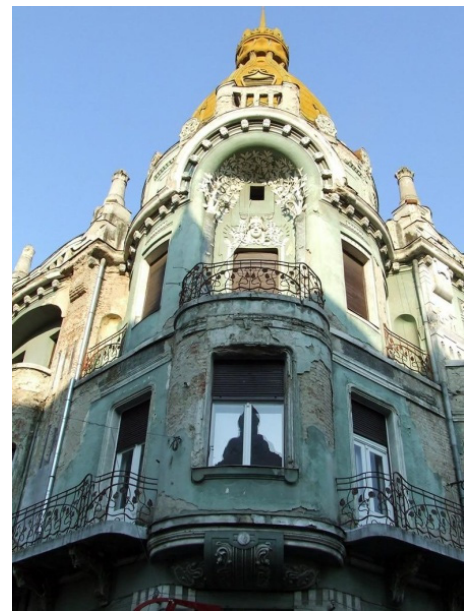

Figure 21. Moskovits Miksa Palace (1904-1905), architect Kálmán Rimánoczy Jr., Oradea before restoration (photo: M. Bostenaru, 2009).

Unlike in the case of Italy, in Romania concrete did not spread wide as early as the Hennebique system, but spread widely instead suddenly during the interwar period, the potential of the material being insufficiently researched, especially given the earthquakes which occur here. Numerous buildings on the Magheru Boulevard (Figure 12) collapsed, rendering the material vulnerable. Today, how to retrofit them is being discussed and there is some state support for this.

\subsection{Hungary}

Szilárd Zielinszky built a number of water towers in Hungary [55], the first one in Kőbánya in 1903, demolished in 1968. Some others have been refurbished, for example the one in Szeged (1904), which has been also strengthened 2005-2006 [55] avoiding corrosion, in frame of the rehabilitation of the whole open place, and the one on Margaret Island in Budapest (1911) UNESCO monument, architect Ray Rezsô Vilmos, converted in an arts gallery since 2012. In both cases architects have been involved in the refurbishment to make participative architecture out of concrete heritage. There is one more water tower by Zielinszky on the Svábhegy in Budapest and other important ones in Szolnok, Hungary, and in Beočin, Serbia [55]. After the same technique as the tower on Margaret island the water tower in Siófok was designed by Árpád Gút (1877 in Kéthely-24 May 1948 in Tel Aviv) and Jenó Gergely in 1912 [57] (Figure 22). The tower was altered 1935, and then renovated in the interior in 1998. 
In 2010-2012, the exterior was also renovated, now being a complete touristic highlight in the Balaton lake area. Arpád Gút later built a notable (for his memories [57]) water tower in Tel Aviv, Maze street (1924), with a menorah (a traditional Hanukah candelabrum) on the top (during the Festival of Lights), after he emigratedin Israel in 1921. The water tower is still staying. The water tower was renovated 2010-2016 [58].

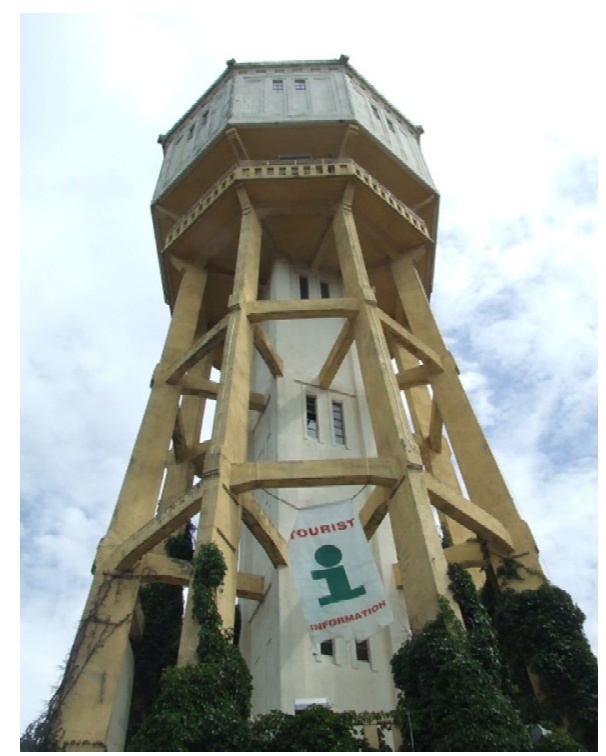

Figure 22. Watertower in Siófok, Hungary (photo: M. Bostenaru, 2009, before exterior renovation).

Art Nouveau construction following the French legacy is also very rarely to be found in the neighboring country of Hungary, to which Transylvania, now part of Romania, belonged that time, the only notable building being the Palais Reők in Szeged (1907), by Ede Magyar (Figure 23) (31 January 1877 in Orosháza-5 May 1912 in Szeged, Austria-Hungary), which recently (2007) underwent restoration.

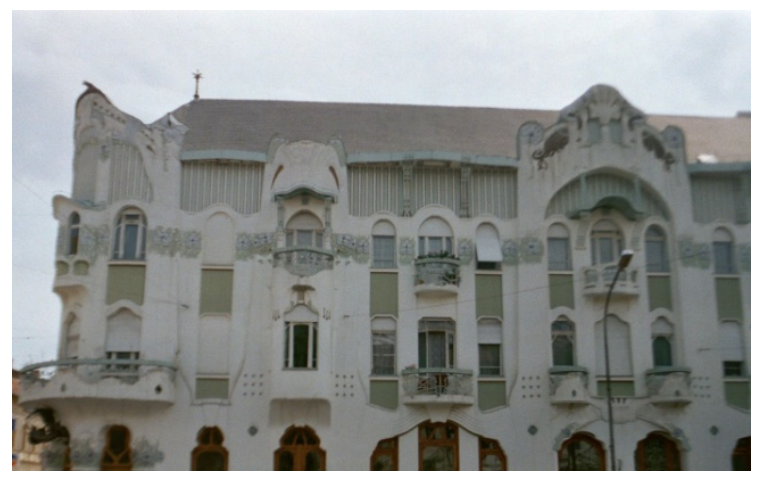

Figure 23. Palais Reők, Szeged (1907), architect Ede Magyar, before restoration (photo: M. Bostenaru, 1999).

It is debatable whether the architecture of the National Romantic style, as it is called in Hungary and Latvia, is to be considered Art Nouveau, and whether the New-Romanian style belongs to this.

Reinforced concrete, in Hennebique system, is also documented in the archives on the works of Béla Lajta (23 January 1873 in Óbuda, Austria-Hungary-12 October 1920 in Vienna, Austria) in Budapest [59], the one mentioned with the Népszinház street building and its concrete language, highlighting a composition with light weightthrough skeleton in the lower storeys and heavy load bearing masonry in the upper storey, as with Loos' architecture (Figure 24). This is an early example of Art Deco at the time of Art Nouveau, which is to be found also in Bucharest in the Santa Elena church of the Hungarian community. Also from Austria-Hungary (Slovenia), Jože Plečnik (23 January 
1872 in Ljubljana, Austria-Hungary-7 January 1957 Ljubljana), built the first church in reinforced concrete in Vienna (1910-1913), Austria (Figure 25), with its skeleton framework located in the basement. This created a unique language which highlights the difference between a hall and a storey-wise construction [6]. However, in his hometown of Ljubljana, Plečnik preferred masonry to reinforced concrete.

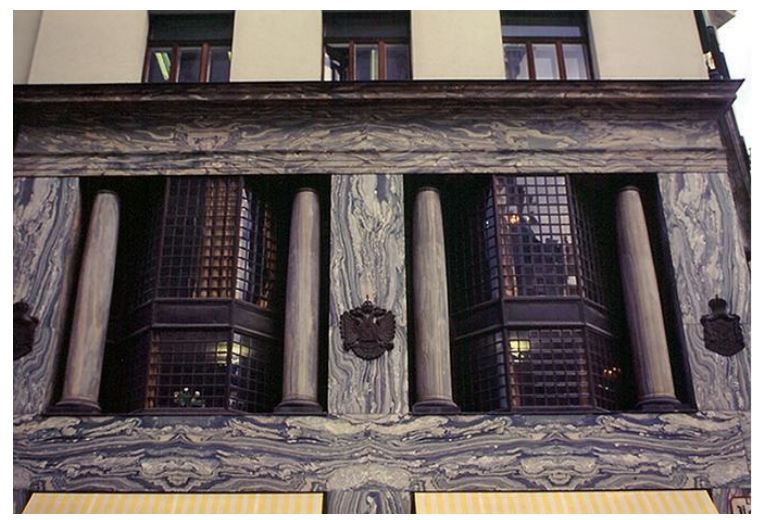

(a)

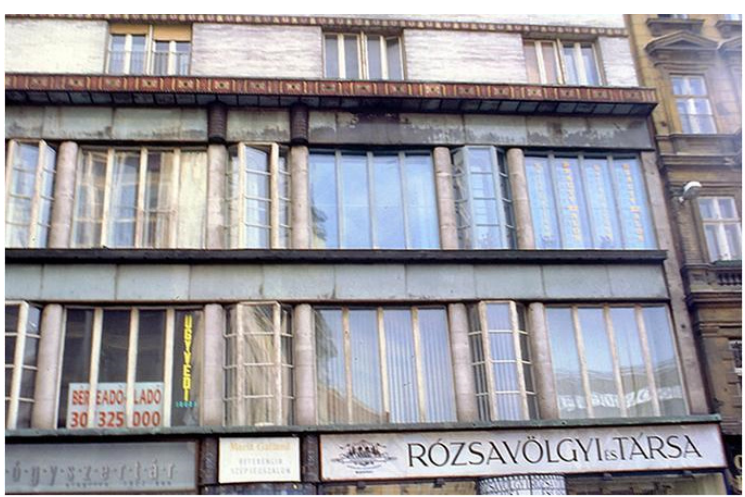

(b)

Figure 24. (a) Loos house at Michaelerplatz, Vienna (photo: M. Bostenaru, 2006); (b) Rózsavölgyi house, Budapest, architect Béla Lajta (photo: M. Bostenaru, 1997).

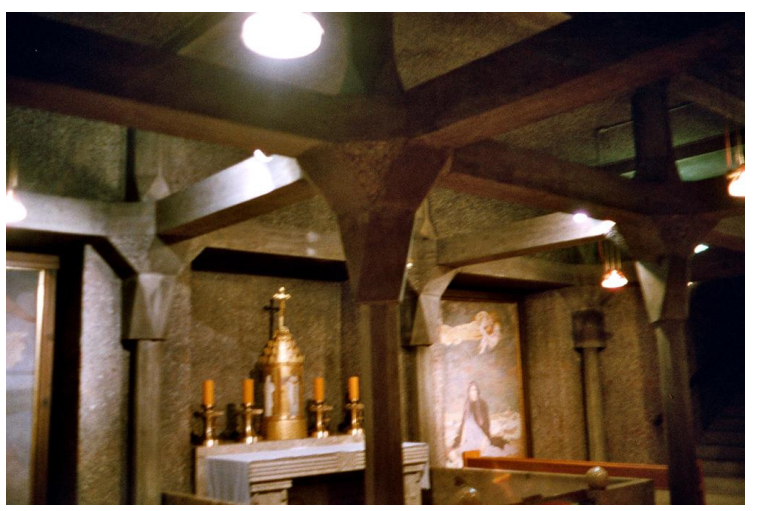

Figure 25. Church of the Holy Spirit (1910-1913), Vienna, architect Jože Plečnik, (Photo: M. Bostenaru, 2005).

\subsection{Portugal and Latvia}

Also in Portugal, reinforced concrete was first employed in industrial architecture, where Bernardo Joaquim Moreira de Sá (1879-1919), later with the company Moreira de Sá \& Malevez (MS\&M), were Hennebique's agents $[60,61]$. Reinforced concrete for the Medicine School in Lisbon was tested 1898 by Paul Cottancin himself [61]. Some notable constructions of them are bridges, of which not all survived time being demolished in frame of further construction works on the rivers (ex. a dam submerged the Luis Bandeira Bridge from 1906/1907, the oldest in concrete in use in Portugal and one of the oldest in Europe until recently [62]). Other industrial buildings by Hennebique's agents in Portugal are water towers [60]: the reservoirs in Lisbon Penha de Franca district and Barreiro, both from 1907. Lisbon features a water museum on four historic sites which have to do with water, but the tower is not part of this. In Barreiro, there was recently a call for artists to reuse the tower.

Kratins and Tipane [63] list these industrial buildings as being part of its Art Nouveau architectural heritage, for example the Water tower of Agenskalns, on Alises 4 (1910) by Wilhelm Bockslaff (24 October 1858 in Riga, Latvia-9 March 1945 in Posen), along with examples of National Romantic, classified as such also by [64] along with the Ciekurkalns (1912-1913) water tower. Both water towers functioned long and are still standing today. A discussion on opportunities of conversion of water towers, especially in Romania, is given in [65]. The contribution highlights that few water towers 
are in reinforced concrete, like those in Portugal in Hennebique technique, although, in this paper, the one by Virginia Haret, not kept in Bucharest, is documented in Figure 16. Also, the water tower on Angenskalns is discussed in [65]: the tower was raised and extended in 1937 and converted 1991-2010 for creative industries.

In his own house (1903, Bourg-la-Reine by Paris), Hennebique had used the volumetric shape of industrial architecture, including a water tower [65], an architecture in which his system spread so much. The villa is protected as monument, but it was renounced at some of the original functions, such as the roof garden, while it is subdivided into more flats.

\subsection{Britain and Germany}

In Britain and Germany Hennebique's representatives were Mouchel and Züblin respectively [66]. The first documented case of use of Hennebique's system in Britain was Weaver's mill in Swansea in 1897, followed by industrial, co-operative, railway, and silo buildings, while framed buildings in non-Hennebique's system appeared after 1905 [67]. Louis Gustave Mouchel (11 January 1852 in Cherbourg-27 May 1908 in Cherbourg, France) founded with the Hennebique licence 1897 the company in Briton Ferry in the UK, where he spent most of his adult life. The company Züblin was founded by Swiss engineer and pioneer of iron concrete construction Eduard Züblin (11 March 1850 in Castellammare di Stabia, Italy-25 November 1916 in Zürich, Switzerland). The Technical University of Vienna in a team lead by Vittoria Capresi analyzed an example of the application of the Hennebique system, also using pre-cast elements made and imported from Belgium: the Baron Palace in Cairo [68], where Hennebique constructed already in 1895 [62].

In frame of the COST action TD1406 some case studies in "Innovation in intelligent management of heritage buildings" were studied by the author of this paper, including in Bucharest, Romania and Karlsruhe, Germany. One of the case studies in Germany was the building of the ZKM (Centre for Arts and Media), former munitions factory (1915-1918) now museum and arts university (Figure 26). The building is listed as building of special importance according to the monument law. Philipp Jakob Manz (2 December 1861 in Kohlberg-2 January 1936 in Stuttgart), an important architect of German industrial architecture, including textile architecture, and also for water works [69], was the architect of the initial industrial building. Manz used here for the first time a frame construction in Hennebique technique [69]. The industry hall is the only one remaining from a larger industry area. In the last decades a new function was searched for it. The conversion took place 1993-1997 [70]. Architects of the reconstruction were the office Schweger and Partner. Parts were added like a cube for the entrance. The windows were changed, the new cube is in steel, and the old building is reinforced concrete in Hennebique system, one of the most advanced at its time. New stairs from timber and steel were added in the interior, as well as passages over the atria. The building is very large and the only one remaining from an industry areal and it was difficult to use the atria. The combination of a museum and art school is very good.

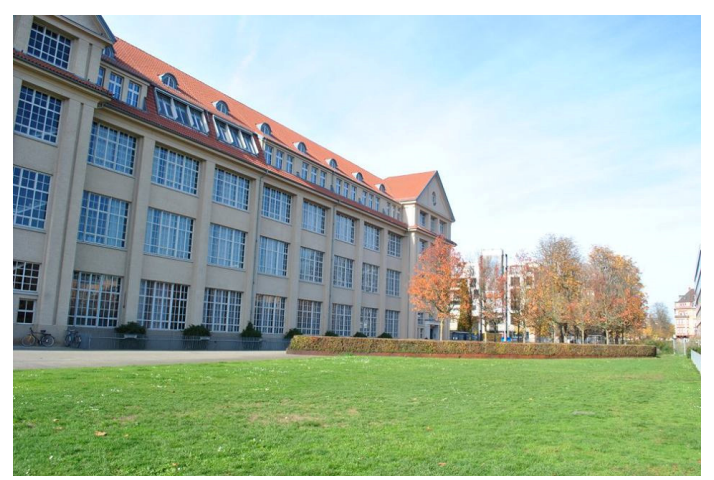

(a)

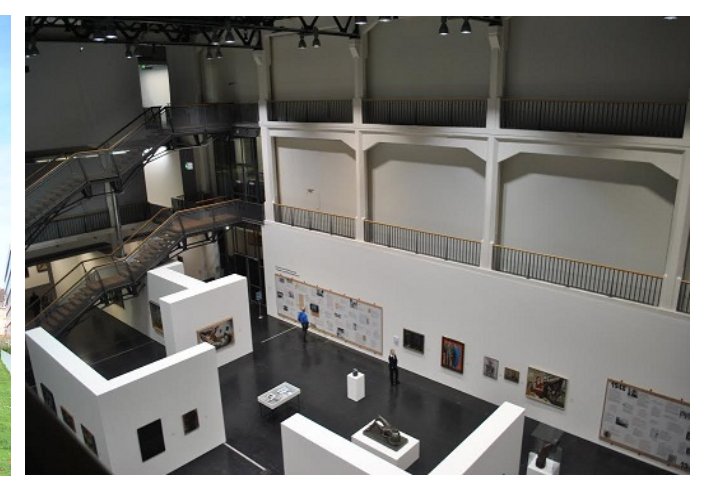

(b)

Figure 26. ZKM museum and art university building in Karlsruhe (1915-1918, conversion 1993-1997), Germany. (Photos: M. Bostenaru, 2016). (a): ZKM museum; (b): art university building. 


\section{Discussion and Conclusions}

Early reinforced concrete represents a stage in the development of a new material of importance for the history of construction. To date, this has been insufficiently researched, as it is rare that the history of architecture highlights the structure of a building. There is a need for research on this aspect, in order to be able to select constructions worth preserving as innovative landmarks in the structural system. This approach was called for at the f.i.b. (federation internationale du beton) Congress in Naples in 2006. The International Congress on Construction History, at its 6th edition in 2018 bridged this gap following initiatives in the UK and US, while in Germany architecture history chairs are often called "Baugeschichte" (construction history). The discipline of history of technology has a slightly different focus also regarding construction, and issues such as architecture and acoustics are touched, but not so much the relationship between structures and architecture as in the triennial conference series "Structures and architecture" in Guimarães, Portugal, mentioned in [11]. In Portugal also restoration includes architecture and civil engineering aspects in an exemplary synergy.

In the meantime, the multidisciplinary approach between philosophy, architecture, and technical sciences (including sciences related to materials such as civil engineering but also chemistry) is important in order to fully assess the cultural significance one may attribute to material authenticity. Materials can be technically assessed and also produced, but it is necessary to understand their relationship to architectural shape, which is given by a philosophical view of the theory of architecture. Notable, in this analysis on concrete, is the relationship to timber as the architectural language had been developed, a relationship which is negated by today's different seismic performance of reinforced concrete and timber. Art Nouveau was one of the many styles adopted by buildings with reinforced concrete structures. Others display Classical features, or were industrial buildings. But, common to both the development of reinforced concrete and the birth of Art Nouveau was the quest for a new style. Reinforced concrete called for a unique language across geographies. Apart of the housing or public buildings which display a style, the material has been used in numerous industrial buildings including water towers and also bridges. The house of Hennebique featured a water tower, as a symbol of the combination of residential and industrial architecture. For industrial buildings, with the economic shift today, challenges are different. For example, water towers were an architectural program which was in function only for a short time. In this case, in the decision of functional or material reuse, a new philosophy of the material, looking to the past, needs to be elaborated. Keeping the original material also contributes to the authenticity of the site, as architectural charters call for. In this sense, self-healing, as recently researched, is a promising technique for reinforced concrete as for natural materials such as stone.

When reinforced concrete was introduced, it was considered a material to last forever. It generated great enthusiasm through the plastic capacity to fill any shape and through the ability to be industrially employed in large scale. This is shown also by the provided either industrial examples and/or with shapes expressing the philosophy behind the material. The search for a new language in architecture was combined with the search for a new language for the material. For this reason, it was employed at larger and larger scale. With time, durability proved much different. First only about a century displayed age alteration, second, where it was subjected to earthquakes, conflicts aroused between the flexibility it allowed in the floor plan and the necessities to resist horizontal loads. The plastic possibilities proved in contradiction with sustainability. Hence, today discussions on sustainability of concrete are different. Looking to the economic considerations of reuse against new construction is exceeding the frame of this paper, but thoughts are addressed today to economics of conservation, for example in the ICOMOS (International Council on Monuments and Sites) ISCEC (ICOMOS International Scientific Committee on Economics of Conservation) international scientific committee. Since many of these constructions are listed as monuments also because of their creative use of an early technology, furthering the impulses at the mentioned f.i.b. conference could be done in this direction. Reuse attempts shall consider the cultural, architectural, environmental value of the buildings in their surroundings, not just in case the building is listed as a monument, as in the European Charter of 
the Architectural Heritage from 1975, the European Architectural Year. Reuse is also reducing the energetic footprint which new constructions would generate. The examples provided in this paper show different creative ways of reuse for industrial and non-industrial buildings, including functional conversion, extension or replacement of parts related to functional conversion, or monument adequate restoration. In a few cases demolition could not be avoided, but some example reused the material through recycling. In the case of industrial buildings, such as silos, factories, and water towers, an additional challenge is given by the change of function compared to the time when they were built, and conversion to functions related to creative industries is done today in some cases. In the case of inner-city buildings instead, restoration of primarily the facades was done, accompanied sometimes by a change of functions as in Genoa. The tendencies are similar across Europe, in Eastern as in Western Europe already, which show lessons learned today 30 years after the fall of the Iron Curtain and return to the integration as at the time when these buildings were done and the architects travelled across Europe to learn the newest technologies from Paris and from Hennebique. The lessons reached countries neighboring Europe. The issue of local materials considered in today's sustainability studies is colliding in the case of reinforced concrete, exactly with the philosophy of the material at the beginning of its employment, namely in international employment across countries and styles in Europe and beyond. The spirit of the time, at that moment, of enthusiasm of the industrial revolution was looking for new materials such as steel/iron, glass, and concrete. Today, we shall return at a mix of tradition and innovation which had early expressions at some of the architects of the time, who included local materials such as timber and stone in the language of Modernism in Romania (villas in Bucharest but mainly in Baltchik, Bulgaria by Henrietta Delavrancea-Gibory, a contemporary of Virginia Haret in Romania, but in a different style) or in Estonia (limestone Art Nouveau for example in central Tallinn, Estonia, another Baltic country, on Pikk street by Jaques Rosenbaum around 1909). This mix of tradition and innovation can be followed also in interventions on existing buildings, as the architecture of Carlo Scarpa in Veneto in Italy, in the attention to detail taught already at the end of the 20th century. The layering showing the material is an example on how it can be dealt with its authenticity following monument protection documents and is also a proof of respecting tectonic such as in the philosophy of the material concrete. There is plenty of inspiration in local architecture as a solution for these global challenges.

Funding: This research received no external funding.

Acknowledgments: This work is based on a presentation held at the Art Nouveau Historical Lab 3 "Nature, Creativity and Production at the Time of Art Nouveau" held on the 19th of November 2011 in Milan by the Reseau Art Nouveau Network within the European project "Art Nouveau and Ecology". The Romanian version before revision has been included in the doctorate and some insights regarding early reinforced concrete (not just in Hennebique system) are thus given in Bostenaru Dan, Maria, Dill, Alex and Gociman, Cristina Olga (2015) Digital architecture history of the first half of the 20th century in Europe, Editura Universitară "Ion Mincu", Bucharest, available in the ICOMOS open archive. The author is grateful for the comments of three anonymous reviewers and of the academic editor which helped improving the paper a lot.

Conflicts of Interest: The author declares no conflict of interest.

\section{References}

1. Monteiro, P.J.; Miller, S.A.; Horvath, A. Towards sustainable concrete. Nat. Mater. 2017, 16, 698-699. [CrossRef]

2. Podestà, S.; Scandolo, L. La valutazione della sicurezza nelle strutture storiche in c.a. Progett. Sismica 2010, 2, 67-78.

3. Mindess, S.; Aitcin, P.-C. Sustainability of Concrete; Taylor \& Francis Group: New York, NY, USA, 2011.

4. Sakai, K.; Noguchi, T. The Sustainable Use of Concrete; Taylor \& Francis Group: New York, NY, USA, 2012.

5. Dan, M.B. Integrated System for Building Survey and Evaluation of Seismic Retrofit Possibilities. Wit Trans. Built Environ. 2003, 66, 555-564.

6. Dan, M.B. (Ne) Sinceritatea în expresia exterioară: Structuri spaţiale în arhitectura de avantgardă. Construcţii Civ. Şi Ind. 2005, 69, 30-35.

7. Nicoletti, A.M.; Manara, E.; Bozzo, G. Genova. In Il Palazzo Della Nuova Borsa; SAGEP: Genova, Italy, 1999. 
8. Mezzina, M.; Palmisano, F.; UvaG. Reinforced Concrete Constructions at the Beginning of the 20th Century: Historical Review and Structural Assessment. In Materials, Technologies and Practice in Historic Heritage Structures; Bostenaru Dan, M., Přikryl, R., Török, Á, Eds.; Springer: Dordrecht, The Netherlands, 2010.

9. International Committee for Conservation of Industrial Heritage. The Nizhny Tagil Chartel for the Industrial Heritage. In Proceedings of the XIIth International Congress of TICCIH, Moscow, Russia, 17 July 2003.

10. Berndt, M.L. Properties of Sustainable Concrete Containing Fly Ash, Slag and Recycled Concrete Aggregate. Constr. Build. Mater. 2009, 23, 2606-2613. [CrossRef]

11. Paulo, B. Lourenco (University of Minho, Guimarães, Portugal). Personal Communication at the Structures and Architecture Conference 21-23 July 2010; Where a Related Paper was Presented, and Later Published. Available online: http://www.icsa2010.arquitectura.uminho.pt/ (accessed on 22 July 2020).

12. Kramm Et Strigl. Verwaltungsgebäude und Parkhaus Vilbeler Weg. Bürgerparkviertel Darmstadt. Available online: https://www.kramm-strigl.de/index.php/darmstadt-verwaltung-und-parkhaus.html (accessed on 19 June 2020).

13. Fischer, T. Die Waldspirale. Z. Geodäsie Geoinf. Landmanag. 2002, 127, 211-220.

14. Jonkers, H.M.; Thijssen, A.; Muyzer, G.; Copuroglu, O.; Schlangen, E. Application of Bacteria as Self-Healing Agent for the Development of Sustainable Concrete. Ecol. Eng. 2010, 36, 230-235. [CrossRef]

15. Theodoridou, M.; Harbottle, M. Preventing Deterioration of Construction Geo-Materials; the New Concept of Biological Self-Healing for Porous Building Stone. Geophys. Res. Abstr. 2018, 20, EGU2018-13831.

16. Nardi, C.D.; Theodoridou, M.; Sim, P.; Harbottle, M.; Jefferson, A.D. Self- Healing Lime-Based Mortars using Biological Mechanisms and Microvascular Networks. In Proceedings of the 5th Historic Mortars Conference, Pamplona, Spain, 19-21 June 2019.

17. Frampton, K. Studies in Tectonic Culture. The Poetics of Construction in Nineteenth and Twentieth Century Architecture; MIT Press: Cambridge, MA, USA, 1995.

18. Schultz, A.-C. The Process of Stratification in the Work of Carlo Scarpa. Ph.D. Thesis, Universität Stuttgart, Stuttgart, Germany, 1999. Available online: http://elib.uni-stuttgart.de/opus/volltexte/1999/514/ (accessed on 11 July 2020).

19. Bötticher, C. Die Tektonik der Hellenen; Nabu Press: Berlin, Germany, 2012. [CrossRef]

20. Semper, G. Der Stil in den Technischen und Tektonischen Künsten, oder Praktische Aesthetik: Ein Handbuch für Techniker, Künstler und Kunstfreunde; ETH-Bibliothek Zürich, Rar 6712; Verlag für Kunst und Wissenschaft: Frankfurt, Germany, 2016; pp. 1860-1863. [CrossRef]

21. Moravánszky, A. Stoffwechsel: Materialverwandlung in der Architektur; Birkhäuser: Basel, Switzerland, 2017.

22. Moravánszky, A. Die Architektur der Donaumonarchie 1867 bis 1918; Ernst \& Sohn: Berlin, Germany, 1988.

23. Sandaker, B. An Ontology of Structured Space. In Structures and Architecture; Cruz, P.J.S., Ed.; CRC Press: Leiden, The Netherlands, 2010; pp. 11-14.

24. Berlage, H.P. Thoughts on Style, 1886-1909; Getty: Los Angeles, CA, USA, 1996; Available online: http: //www.getty.edu/publications/virtuallibrary/0892363347.html (accessed on 23 June 2020).

25. Heidegger, M.; Kleininger, T.; Liiceanu, G., Translators; Originea operei de Artă; Humanitas: Bucharest, Romania, 1995.

26. Harries, K. Art Matters. A Critical Commentary on Heidegger's: The Origin of the Work of Art; Springer: Dordrecht, The Netherlands, 2009.

27. Dustin, C.A.; Ziegler, J.E. Thinking as Craft: Heidegger and the Challenge of Modern Technology. In Practicing Mortality: Art, Philosophy, and Contemplative Seeing; Palgrave Macmillan: New York, NY, USA, 2005; pp. 167-192.

28. Nara Document from 1994. Available online: https://www.icomos.org/charters/nara-e.pdf (accessed on 12 May 2020).

29. Choisy, A. L'Art de Bâtir Chez les Byzantines. 1873. Available online: https://bibliotheque-numerique.inha. fr/collection/item/16243-1-art-de-batir-chez-les-byzantins?offset=3 (accessed on 12 May 2020).

30. Le Corbusier. Towards a New Architecture; Etchells, F., Translator; J. Rodker: London, UK, 1931; Reprint New York: Dover Publications, 1985; Available online: https://archive.org/details/in.ernet.dli.2015.208774/page/n5 (accessed on 23 June 2020).

31. Peschken, G.; Schinkel, K.F. Das architektonische Lehrbuch. Habilitation; Deutscher Kunstverlag: Berlin, Germany, 2001.

32. Deleuze, G. Mille Plateaux; Minuit: Paris, France, 1980; pp. 592-625. 
33. Gravagnuolo, B. Gottfried Semper, Architettura Arte e Scienza: Scritti scelti, 1834-1869; CLEAN: Naples, Italy, 1987.

34. Wagner, O. Moderne Architektur: Seinen Schülern ein Führer auf diesem Kunstgebiete; ETH-Bibliothek Zürich, A 832; Schroll: Vienna, Austria, 1898. [CrossRef]

35. Schwarzer, M. Ontology and Representation in Karl Bötticher's Theory of Tectonics. J. Soc. Archit. Hist. 1993, 52, 267-280. [CrossRef]

36. Mina, L. Il Cemento Armato e lo Stile Nuovo. L'artista Mod. 1905, IV , 73-78.

37. Mendelsohn, E.; Beyer, O.; Grote, C. Briefe eines Architekten; Prestel: Munich, Germany, 1961.

38. Benkő-Medgyaszay, I. Über die künstlerische Lösung des Eisenbetonbaues. In Berichte über den VIII. Internationalen Architektenkongreß Wien 1908; Wien, A. Schroll \& Co.: Vienna, Austria, 1909; p. 538ff.

39. Huse, N. Mendelsohn—der Einsteinturm. die Geschichte einer Instandsetzung; Krämer: Stuttgart, Germany, 2000.

40. Moravánszky, Á. Die Architektur der Jahrhundertwende in Ungarn und ihre Beziehungen zu der Wiener Architektur der Zeit; Verband der Wissenschaftlichen Gesellschaften Österreichs: Vienna, Austria, 1983.

41. Medgyaszay (Benkó), I. Entwurf eines Warenhauses. Der Architekt. 1903, IX, 24-25.

42. Medgyaszay (Benkó), I. Fassadenentwurf und Grundriß dazu. Der Architekt. 1902, VIII, 36.

43. Nelva, R.; Signorelli, B. Avvento ed Evoluzione del Calcestruzzoarmato in Italia: Il Sistema Hennebique; Associazione Italiana Tecnico Economica del Cemento, Edizioni di scienza e tecnica: Milan, Italy, 1990.

44. Archivio Porcheddu. Politecnico Di Torino. Available online: http://www.diseg.polito.it/il_dipartimento/ strutture_interne/archivi_e_biblioteche/archivio_porcheddu (accessed on 19 June 2020).

45. Baldescu, I. Anghel Saligny (1854-1925), un Ingegnere sul Cantiere della Romania Moderna. Anniversario 1854-2014, 160 Anni Dalla Nascita; Editura Institutului Cultural Român: Bucharest, Romania, 2014.

46. Băncescu, I. Grain Silos in the Port of Constanţa at the Beginning of the 20th Century. Ephemer. dacorom. Annuario Sc. Romena Roma 2012, XIV, 273-323.

47. Cenci, S.; Sanguineri, M. Genova Hennebique. 2019. Available online: http://www.genovameravigliosa.com/ sites/default/files/BOOK\%20HENNEBIQUE_web_0.pdf (accessed on 18 June 2020).

48. Dinu, Ș. Cazinoul din Constanţa: Un Monument Art-Nouveau la Țărmul Mării Negre. In Dobrogea Culturală între Constanța și Balcic, Istorie, Patrimoniu, Peisaj; ASOCIAȚIA ARCHÉ; Chiciudean, C., Mexi, A., Eds.; Asociaţia ARCHÉ: Bucharest, Romania, 2017; pp. 20-29.

49. Bond, P. Constanta Casino, Romania. Technical Report. 2018. Available online: http://www.europanostra.org/ wp-content/uploads/2018/09/7ME-2018-Romania-ConstantaCasino-Report.pdf (accessed on 18 June 2020).

50. Slav, D. Unicitatea Constanţei-Octogon confesional. In Dobrogea Culturală între Constanța și Balcic, Istorie, Patrimoniu, Peisaj; ASOCIAȚIA ARCHÉ; Chiciudean, C., Mexi, A., Eds.; Asociaţia ARCHÉ: Bucharest, Romania, 2017; p. 16.

51. Marcu, D. Arhitectură 1912-1960; Editura Tehnică: Bucharest, Romania, 1960.

52. Haret, R.S. Virginia Sp. Haret (Andreescu) Prima Arhitectă care a Activat în România (1894-1962). Arhitectura 1976, XXIV, 33-41.

53. Bem, R. Imobilul de Locuinţe de pe Strada Frumoasă 50-56 (1925-1928). In Arhitectura Bucureşteană sec. 19 şi 20; Beldiman, A., Woinaroski, C., Eds.; Simetria ArCuB: Bucharest, Romania, 2000.

54. Paşca, M. Palatul Moskovits Miksa, Oradea. Available online: http://enciclopedie.transindex.ro/monument. php?id=313 (accessed on 16 June 2020).

55. Gábor-Szabó, Z. 100-Year-old Water Towers of the Zielinski Engineers’ Bureau. Period. Polytech. Civ. Eng. 2010, 54, 171-180. [CrossRef]

56. Víztorony (Watertower Database). Available online: https://viztorony.blog.hu/ (accessed on 21 June 2020).

57. Sivan, E. Árpád Gut (1877-1948)—Engineer. 2018. Available online: https://www.izrael70.hu/arpad-gut (accessed on 21 June 2020).

58. Amnon Bar Or-Tal Gazit Architects Ltd. 36 Maze St., Tel Aviv-Yafo-The Water Tower. Available online: http://www.amnon-baror.co.il/?projectpt1=\%d7\%a8\%d7\%97-\%d7\%9e\%d7\%96\%d7\%90\%d7\%94-36-\%d7\% aa \%d7\%9c-\%d7\%90\%d7\%91\%d7\%99\%d7\%91-\%d7\%9e\%d7\%92\%d7\%93\%d7\%9c-\%d7\%94\%d7\%9e\%d7\% 99\% $77 \% 9 d \& l a n g=e n$ (accessed on 21 June 2020).

59. Csáki, T. Lajta Béla VirtuálisArchívum. Available online: http://lajtaarchiv.hu/ (accessed on 31 October 2011).

60. Tavares, A. The Effects of Concrete on Portuguese Architecture: The Moreira de Sá and the Malevez Case (1906-1914). In Proceedings of the Second International Congress on Construction; History, Construction History Society: Cambridge, UK, 2006; pp. 3041-3059. 
61. Mascarenhas-Mateus, J.; Rodrigues de Castro, C. The Portland Cement Industry and Reinforced Concrete in Portugal (1860-1945). In Building Knowledge, Constructing Histories; Wouters, I., Va de Voorde, S., Bertels, I., Espion, B., De Jonge, K., Zastavni, D., Eds.; CRC Press: London, UK, 2018; Volume II.

62. Sena-Cruz, J.; Ferreira, R.M.; Ramos, L.; Fernandes, F.; Miranda, T.; Castro, F. Luiz Bandeira Bridge: Assessment of a Historical Reinforced Concrete (RC) Bridge. Int. J. Archit. Herit. 2013, 7, 628-652. [CrossRef]

63. Krastins, J.; Tipane, A. Art Nouveau in Riga; 19. Rigas Jugendstila Centrs: Riga, Latvia, 2008.

64. Karlstrema, I. Riga's Turn of the Century Water Tower Architecture in the European Context. Maksl. Vestur. Un Teor. 2013, 16, 37-48.

65. Cercleux, A.-L.; Merciu, F.-C.; Peptenatu, D. Conversion of Water Towers-an Instrument for Conserving Heritage Assets. Urban. Archit. Constr. 2014, 5, 2-30.

66. McBeth, D.; Hennebique, F.; Mouchel, L.G. Francois Hennebique (1842-1921)—Reinforced Concrete Pioneer. P I Civil Eng-Civ En. 1998, 126, 86-95. [CrossRef]

67. Cusack, P. Agents of Change: Hennebique, Mouchel and Ferroconcrete in Britain, 1897-1908. Constr. Hist. 1987, 3, 61-74.

68. Capresi, V. Baron Palace Project. Available online: http://baugeschichte.tuwien.ac.at/website/baron-palacedocumentation-project/ (accessed on 12 May 2020).

69. Renz, K. Philipp Jakob Manz (1861-1936): Industriearchitekt und Unternehmer. Ph.D. Thesis, Universität Stuttgart, Stuttgart, Germany, 2003. Available online: http://elib.uni-stuttgart.de/opus/volltexte/2003/1464/ (accessed on 20 June 2020).

70. ZKM. Architecture. Available online: https://zkm.de/en/about-the-zkm/entstehung-philosophie/architecture (accessed on 20 June 2020).

(C) 2020 by the author. Licensee MDPI, Basel, Switzerland. This article is an open access article distributed under the terms and conditions of the Creative Commons Attribution (CC BY) license (http://creativecommons.org/licenses/by/4.0/). 